\title{
FUNCTIONAL ANALYSIS OF THE ARABIDOPSIS PHT4 FAMILY OF INTRACELLULAR PHOSPHATE TRANSPORTERS
}

\author{
A Thesis \\ by \\ BIWEI GUO \\ Submitted to the Office of Graduate Studies of \\ Texas A\&M University \\ in partial fulfillment of the requirements for the degree of \\ MASTER OF SCIENCE
}

May 2008

Major Subject: Biology 


\title{
FUNCTIONAL ANALYSIS OF THE ARABIDOPSIS PHT4 FAMILY OF INTRACELLULAR PHOSPHATE TRANSPORTERS
}

\author{
A Thesis \\ by \\ BIWEI GUO \\ Submitted to the Office of Graduate Studies of \\ Texas A\&M University \\ in partial fulfillment of the requirements for the degree of \\ MASTER OF SCIENCE
}

\begin{abstract}
Approved by:
Chair of Committee, Wayne Versaw

Committee Members, Thomas McKnight

Bruce Riley

Kendal Hirschi

Head of Department, Vincent Cassone
\end{abstract}

May 2008

Major Subject: Biology 


\begin{abstract}
Functional Analysis of the Arabidopsis PHT4 Family of Intracellular Phosphate Transporters. (May 2008)

Biwei Guo, B. S., Wuhan University, P.R.China

Chair of Advisory Committee: Dr. Wayne K. Versaw
\end{abstract}

The transport of phosphate $(\mathrm{Pi})$ between subcellular compartments is central to metabolic regulation. Although some of the transporters involved in controlling the intracellular distribution of Pi have been identified in plants, others are predicted from genetic and biochemical studies. The Arabidopsis thaliana genome encodes a family of six proteins that share similarity with SLC17/type I Pi transporters, a diverse group of animal proteins involved in the transport of $\mathrm{Pi}$, organic anions and chloride.

Heterologous expression in yeast, and gene expression and localization studies in plants were used to characterize all six members of this Arabidopsis family, which we have named PHT4. All of the PHT4 proteins mediate Pi transport in yeast with high specificity. Bioinformatic analysis and localization of PHT4-GFP fusion proteins indicate that five of the proteins are targeted to the plastid inner envelope membrane, and the sixth resides in the Golgi apparatus. PHT4 genes are expressed in both roots and leaves although two of the genes are expressed predominantly in leaves and one mostly in roots. These expression patterns, together with Pi transport activities and subcellular 
locations, suggest roles for PHT4 proteins in the transport of Pi between the cytosol and chloroplasts, heterotrophic plastids and the Golgi apparatus. 


\section{DEDICATION}

This thesis is dedicated to my beloved husband, Xiaoji, and my parents. 


\section{ACKNOWLEDGEMENTS}

I would like to thank my committee chair, Dr. Wayne Versaw. Thank you for guiding me into the world of science and teaching me the way of thinking, which I will always benefit from. Thank you for always being patient and supportive.

I also want to thank my committee members, Dr. McKnight, Dr Riley and Dr Hirschi. Thank you for all the valuable discussions, suggestions, support and challenges.

Thanks also go to my labmates. Thank you for sharing your ideas and for making this lab a fun place to stay.

Finally, thanks to my husband, Xiaoji, for his encouragement and understanding no matter what decision I make. And thanks to my mother for being here with me and giving me unconditional love. 


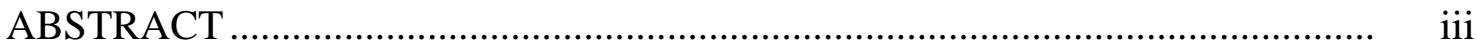

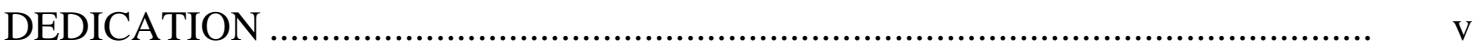

ACKNOWLEDGEMENTS …………………………....................................... vi

TABLE OF CONTENTS .......................................................................... vii

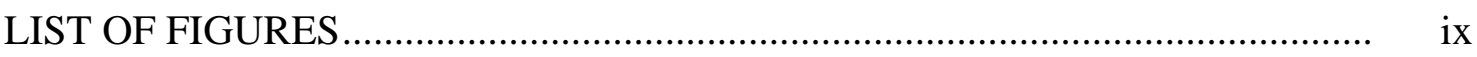

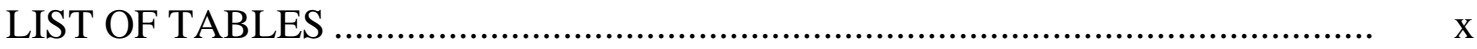

CHAPTER

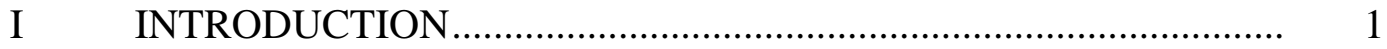

II FUNCTIONAL ANALYSIS OF THE ARABIDOPSIS PHT4 FAMILY OF INTRACELLULAR PHOSPHATE

TRANSPORTERS ….....................................................................

Introduction ........................................................................

Materials and Methods ……………………………………...... 9

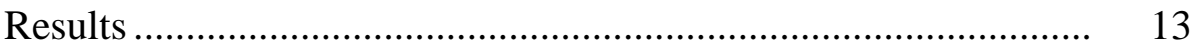

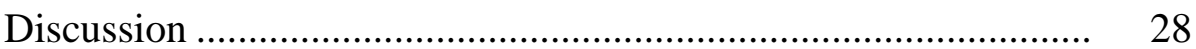

III CONCLUSIONS AND PERSPECTIVES ........................................... 33

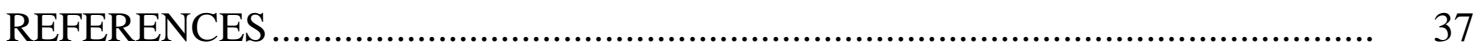

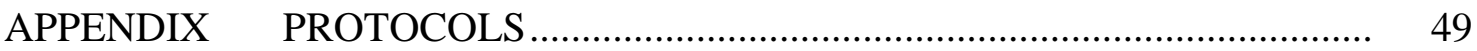

Histochemical GUS Analysis..................................................... 49

Sectioning of GUS Stained Plant Tissue...................................... 50

Quantitative GUS Assay …………………………………........ 52

Hydroponic Growth of Arabidopsis .............................................. 54

Quantitative RT-PCR ……………………................................. 55

PCR Screen for PHT4 Insertion Mutants ....................................... 57

MS Media Recipes ………………………………………......... 59 
Starch Staining of Plant Tissues................................................. 61 Chloroplast Morphology Protocol.............................................. 62

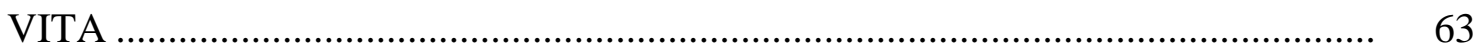




\section{LIST OF FIGURES}

FIGURE Page

1 Phylogenetic analysis of Pi transporter protein sequences........................ 6

2 Complementation of a yeast Pi transport mutant by PHT4 genes............. 16

$3 \quad$ Kinetics of Pi uptake ................................................................. 18

$4 \quad$ Pi uptake as a function of external pH ................................................. 22

5 Subcellular localization of PHT4-GFP fusions .................................... 25

$6 \quad$ Quantitative analysis of PHT4 gene expression in Arabidopsis .............. 26

$7 \quad$ Localization of promoter-GUS gene fusions in transgenic

A. thaliana plants............................................................................ 35 


\section{LIST OF TABLES}

TABLE

Page

1 Members of the Arabidopsis PHT4 family ............................................ 15

$2 \quad$ Apparent $K_{m}$ values for PHT4-mediated Pi transport ............................. 19

$3 \quad$ Specificity and pharmacology of PHT4 transporters ............................. 21 


\section{CHAPTER I}

\section{INTRODUCTION}

Inorganic phosphate $(\mathrm{Pi})$ is an essential macronutrient that is required in every tissue, cell and subcellular compartment of the plant. Pi is a structural component of ATP, nucleic acids and phospholipids, and it is involved in the regulation of innumerable cellular processes through phosphorylation and dephosphorylation reactions. Of central importance to plants, Pi is a substrate and regulator of photosynthesis and of the partitioning of fixed carbon between the starch and sucrose biosynthetic pathways (Walker \& Sivak, 1986). Pi is the sole form of phosphorus that can be assimilated by plants, and it is generally present in soil solution at low micromolar concentrations (Marschner, 1995). As a result, the availability of Pi is often the limiting factor for plant growth.

Plants require multiple Pi transport systems to mediate uptake from the soil and to enable the subsequent distribution of Pi to all of the cells and subcellular compartments of the plant. Some of the transporters involved in these processes have been identified and are classified within distinct families: PHT1, PHT2, PHT3 and pPT (Rausch \& Bucher, 2002; Knappe et al., 2003). In this thesis I will describe the characterization of a novel plant Pi transporter family, which we have named PHT4.

To date, members of the PHT1 family are the only known plant Pi transporters that localize to the plasma membrane. PHT1 transporters were initially identified based

This thesis follows the style of New Phytologist. 
on their similarity to fungal $\mathrm{H}^{+} / \mathrm{Pi}$ symporters from yeast and Neurospora crassa (BunYa et al., 1991; Versaw \& Metzenberg, 1995). The fungal transporters mediate highaffinity Pi uptake from the environment under Pi-limiting conditions, and this physiological role appears to be conserved in plants. PHT1 proteins are located primarily in root epidermal cells, and the respective transcript levels increase under Pi-limiting conditions (Muchhal et al., 1996; Kai et al., 1997; Leggewie et al., 1997; Smith et al., 1997; Daram et al., 1998; Liu, C et al., 1998; Liu, H et al., 1998; Okumura et al., 1998; Smith et al., 1999). Transport experiments using heterologous expression systems indicate that, like their fungal homologs, $\mathrm{PHT} 1$ proteins mediate high-affinity $\mathrm{H}^{+} / \mathrm{Pi}$ symport (Muchhal et al., 1996; Kai et al., 1997; Leggewie et al., 1997; Smith et al., 1997; Daram et al., 1998; Liu, C et al., 1998; Liu, H et al., 1998; Okumura et al., 1998; Smith et al., 1999).

Pi uptake into the mitochondrion is required for the synthesis of ATP through oxidative phosphorylation. Members of the PHT3 family, which share high similarity with mitochondrial Pi carriers of fungal and animal origin, mediate Pi transport across the mitochondrial inner membrane (Kiiskinen et al., 1997; Hamel et al., 2004). Functional analyses of PHT3 proteins in proteoliposomes and in yeast indicate that Pi transport is dependent on a $\mathrm{pH}$ electrochemical gradient and occurs via $\mathrm{H}^{+} / \mathrm{Pi}$ symport (Kiiskinen et al., 1997; Hamel et al., 2004).

Chloroplasts and differentiated heterotrophic plastids, e.g., starch-storing amyloplasts, are bound by a double membrane. The plastid inner membrane is the primary permeability barrier and is the site of a number of proteins involved in the 
transport of Pi between the plastid and cytosol. The chloroplast-specific triose phosphate/Pi translocator was the first such protein to be identified and its gene cloned (Flügge et al., 1989). TPT and related members of the PPT family all mediate stoichiometric exchange of Pi with phosphorylated C3, C5 or C6 compounds (Knappe et al., 2003). The pPT proteins are classified into four subgroups based on preferred substrate: TPT (triose phosphates), PPT (phosphoenol pyruvate), GPT (glucose 6phosphate) and XPT (xylulose 5-phosphate) (Knappe et al., 2003). GPTs are located exclusively in heterotrophic tissues, whereas PPTs and XPTs are located in both photosynthetic and heterotrophic tissues.

Although all members of the PPT family share Pi as a substrate, only TPT directs import of Pi to the chloroplast stroma where it is required to sustain photosynthesis and to coordinate carbon partitioning. Plants with reduced levels of TPT have increased rates of starch turnover and export of neutral sugars to compensate for the inability to directly allocate triose phosphates to the cytosol (Neckelmann \& Orellana, 1998). Surprisingly, these plants have no substantial growth phenotype or reduction in photosynthetic capacity when grown under ambient conditions, which suggests that redundant or compensatory mechanisms also exist for the coupled defect in Pi import. Candidates for this additional Pi import activity include members of the PHT2 family, which share similarity to fungal high-affinity $\mathrm{Na}^{+} / \mathrm{Pi}$ symporters (Versaw \& Metzenberg, 1995; Martinez \& Persson, 1998). The Arabidopsis genome encodes a single transporter of the PHT2 class, PHT2;1 (Daram et al., 1999; Versaw \& Harrison, 2002). GFP fusions and proteomic analysis indicate that PHT2;1 and closely related plant homologs localize to 
the chloroplast inner membrane (Ferro et al., 2002; Zhao et al., 2003; Rausch et al., 2004). Functional analyses in yeast confirmed that PHT2;1 mediates Pi transport, but this activity appears to rely on $\mathrm{H}^{+} / \mathrm{Pi}$ symport rather than $\mathrm{Na}^{+} / \mathrm{Pi}$ symport (Daram et al., 1999; Versaw \& Harrison, 2002; Zhao et al., 2003). Plants that lack PHT2;1 have no obvious photosynthetic defect (Rausch et al., 2004), but do exhibit altered patterns of Pi allocation throughout the plant (Versaw \& Harrison, 2002).

Great progress has been made over the last 10-15 years to identify the transporters responsible for the myriad Pi transport activities that occur in plants. However, biochemical studies have revealed several additional Pi transport activities for which no corresponding transporter has been described. These activities include the constitutive, low-affinity Pi uptake by plant roots (Schachtman et al., 1998), Pi transport into and out of the vacuole, which plays a critical role in homeostasis of cytosolic Pi concentration (Mimura, 1999), and export of Pi from the Golgi apparatus where Pi would otherwise accumulate Pi as a byproduct of protein and lipid glycosylation (Emanuelsson et al., 2000). Similarly, heterotrophic plastids require a mechanism for Pi export to prevent inhibition of starch synthesis (Neuhaus \& Maass, 1996; Neuhaus \& Emes, 2000). The discovery and characterization of the transporters responsible for these and other novel activities are needed to fully understand the metabolic processes that underlie plant growth and development.

In an effort to identify novel plant Pi transporters, we used a bioinformatics approach to screen the Arabidopsis genome for sequences that encode proteins similar to any of a wide range of functionally characterized Pi transporters from bacteria, fungi and 
plants and animals (Versaw \& Harrison, 2002). This search revealed six candidates that share similarity to mammalian type I $\mathrm{Na}^{+} / \mathrm{Pi}$ symporters (solute carrier family SLC17, http://www.gene.ucl.ac.uk/nomenclature), which are unrelated to any of the previously identified plant Pi transporter families (see Fig. 1). We provisionally named this family PHT4. Analysis of the PHT4 protein sequences using subcellular targeting prediction programs, including TargetP v1 (Bannai et al., 2002), PSORT (Nakai \& Kanehisa, 1991), iPSORT , and Predotar v0.5 (http:/www.inra.fr/predotar/) suggested that PHT4 proteins are targeted to either plastids, mitochondria or the secretory pathway. The objectives of this thesis were to determine whether the PHT4 genes encode functional phosphate transporters, and if so, where in the plant these transporters function. 


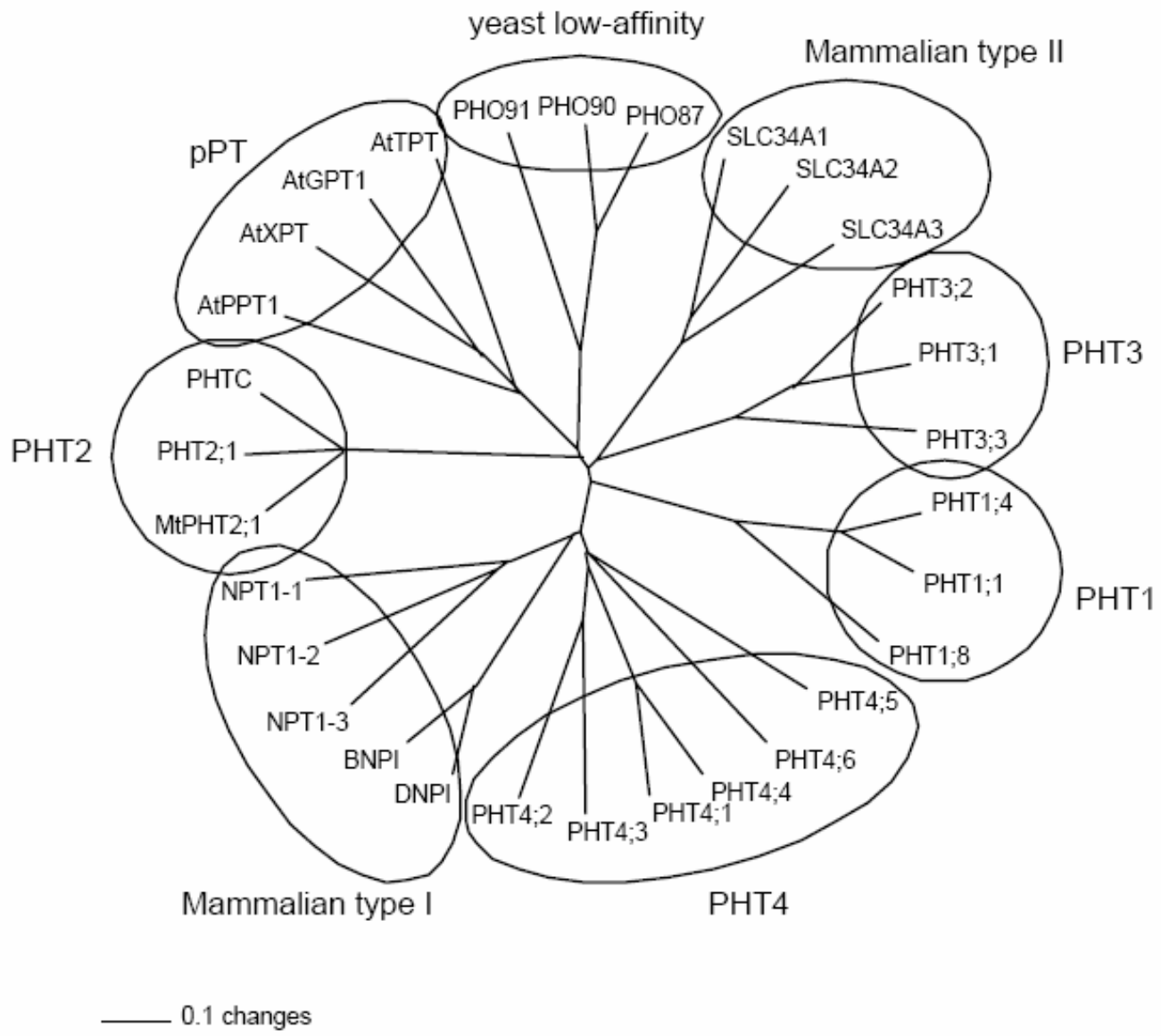

Fig. 1 Phylogenetic analysis of Pi transporter protein sequences. The unrooted, neighbor-joining tree was prepared from a ClustalX alignment using the PAUP* 4.0 tree-building program. 


\section{CHAPTER II}

\section{FUNCTIONAL ANALYSIS OF THE ARABIDOPSIS PHT4 FAMILY OF INTRACELLULAR PHOSPHATE TRANSPORTERS*}

\section{Introduction}

Inorganic phosphate (Pi) is an essential nutrient that is found in every compartment of the plant cell and serves a wide range of structural and regulatory roles, including the modulation of glycolysis, respiration, photosynthesis, and starch and sucrose biosynthesis (Plaxton \& Carswell, 1999). With the exception of the vacuole, the levels of Pi in each compartment are maintained within relatively narrow limits despite large diurnal changes in metabolic demand and often, a scarce supply from soil (Marschner, 1995). This homeostatic control is achieved, at least in part, through metabolic recycling and the selective transport of Pi across the cellular membranes (Mimura, 1999; Raghothama, 1999; Poirier \& Bucher, 2002).

Some of the transporters involved in moving Pi into plant cells and between different cell compartments have been identified. These proteins and their respective homologs are classified into four families: PHT1 (plasma membrane), PHT2 (plastid inner envelope), PHT3 (mitochondrial inner membrane) and pPT (plastid inner envelope)

*Reprinted with permission from "Functional analysis of the Arabidopsis PHT4 family of intracellular phosphate transporters" by Guo, B., Jin, Y., Wussler, C., Blacaflor, E. B., Motes, C. M., Versaw, W. K. 2008, New Phytologist, 177, 889-898. Copyright [2008] Guo et al. 
(Rausch \& Bucher, 2002; Knappe et al., 2003). Biochemical studies have revealed several transport activities that correspond to additional, as yet unidentified, Pi transporters that participate in the subcellular distribution of Pi. These activities include vacuolar import (Massonneau et al., 2000), export from amyloplasts that is not directly coupled to transport of phosphorylated organic compounds (Neuhaus \& Maass, 1996), and export from the Golgi apparatus where $\mathrm{Pi}$ is generated as a by-product of protein and lipid glycosylation (Neckelmann \& Orellana, 1998). The discovery and functional characterization of the Pi transporters responsible for these and other novel Pi transport activities is needed to provide a clearer understanding of how plants coordinate the use of Pi to support growth and development.

We previously noted sequences in the Arabidopsis genome that encode proteins with similarity to mammalian type I Pi transporters (solute carrier family SLC17, http://www.gene.ucl.ac.uk/nomenclature), and that some of these proteins are predicted to be targeted to plastids (Versaw \& Harrison, 2002). More extensive bioinformatic studies (Ward, 2001; Schwacke et al., 2003; Roth et al., 2004) indicated that these sequences constitute a six-member family, and localization studies verified that two of the proteins reside in the chloroplast inner envelope membrane (Ferro et al., 2003; Roth et al., 2004). In this study, we evaluated the biochemical function of all six members of this family and confirmed that each mediates Pi transport when expressed in yeast. In accord with established nomenclature for plant Pi transporters (Bucher et al., 2001; Mudge et al., 2002; Poirier \& Bucher, 2002; Rausch \& Bucher, 2002) we have designated this family PHT4. In addition, results of expression and subcellular 
localization studies suggest that members of the PHT4 family function in chloroplasts, non-photosynthetic plastids and the Golgi apparatus.

\section{Materials and Methods}

\section{DNA constructs}

cDNAs for the full coding regions of each of the six PHT4 genes were produced by RT-PCR using RNA isolated from 5-week old Arabidopsis (ecotype Col-0) plants. PCR primers were designed to introduce unique restriction sites at the 5' and 3' ends of the genes (BamHI and XhoI, respectively, for PHT4;1, and EcoRI and XhoI, respectively, for the other five genes). The cDNA amplicons were cloned into the yeast expression plasmid pWV3 (Versaw \& Harrison, 2002). The PHT4;1( $\Delta 1-59)$ clone was generated by PCR and lacks the first 177 bp of the PHT4;1 coding sequence, which corresponds to a 59-amino acid putative transit peptide, and a new ATG start codon was inserted. For subcellular localization experiments, full-length PHT4 coding sequences were amplified from the plasmids described above then cloned in frame upstream of the green fluorescence protein (GFP) gene in the plasmid CaMV35S-sGFP(S65T)-nos (Chiu et al., 1996). Cloned inserts for all plasmids were sequenced.

Yeast growth and Pi transport measurements

Constructs were tested for their ability to complement the growth defect of the yeast Pi transport-deficient strain PAM2 (Martinez \& Persson, 1998). Transformed yeast were 
grown in SD medium containing $0.22 \mathrm{mM}$ Pi and $25 \mathrm{mM}$ Na-citrate buffer $\mathrm{pH} 4.5$ to an $\mathrm{OD}_{600}$ of 1.0. OD 600 was monitored with a Beckman Coulter DU530 spectrophotometer (Fullerton, CA) equipped with a turbidity cell holder, and a value of 1.0 corresponded to approximately $1 \mathrm{mg}$ cells $/ \mathrm{ml}$. Cultures that grew to densities greater than $\mathrm{OD}_{600}=1.0$ were discarded or diluted once with fresh medium to an $\mathrm{OD}_{600}$ of no greater than 0.1 and re-grown. This growth regime was adopted because it was determined empirically that cells grown in rich medium or to higher densities failed to yield consistent results in subsequent analyses. Cells were harvested by centrifugation, washed with water then suspended to an $\mathrm{OD}_{600}$ of 10.0 , and $5 \mu \mathrm{l}$ aliquots of serial dilutions were spotted to agar plates containing SD medium, $1 \mathrm{mM}$ Pi and $25 \mathrm{mM}$ Na-citrate buffer $\mathrm{pH}$ 6. Plates were incubated at $30^{\circ} \mathrm{C}$ for up to three days. For ${ }^{32} \mathrm{Pi}$ uptake assays, transformed yeast were grown as described above, washed twice with ice-cold water then suspended at $200 \mathrm{mg}$ cells/ml. $10 \mu \mathrm{l}$ of the cell suspension were added to $185 \mu \mathrm{l}$ of Pi-free medium pH 4.0 and equilibrated at $30^{\circ} \mathrm{C}$ for 4 min with gentle agitation. Transport assays were initiated by addition of $5 \mu \mathrm{l}$ of ${ }^{32} \mathrm{Pi}$ at the desired concentration and terminated by the addition of 4 $\mathrm{ml}$ of ice-cold $25 \mathrm{mM}$ Na-citrate buffer followed immediately by filtration on glass fiber filters and an additional wash. The accumulated radioactivity was measured by scintillation spectroscopy. Kinetic data were analyzed by nonlinear regression.

Plant growth conditions

Plants were grown in chambers at $21^{\circ} \mathrm{C}$ with $70 \%$ relative humidity and a 14 -h photoperiod (150 $\left.\mu \mathrm{mol} \mathrm{m} \mathrm{m}^{-2} \mathrm{~s}^{-1}\right)$. For expression studies, individual seeds were placed in 
$0.2 \mathrm{ml}$ tubes containing agar-solidified, half-strength MS medium (Murashige \& Skoog, 1962) lacking a carbon source then stratified for 3 days at $4^{\circ} \mathrm{C}$ before transfer to a growth chamber. After 3-4 days in the growth chamber the tube bottoms were removed and the seedlings were suspended in $1.5 \mathrm{~L}$ growth vessels (Tocquin et al., 2003) containing half-strength MS medium (24 plants per vessel). Plants were grown for 3 weeks before the solution was replaced with either the same replete medium (1.25 mM Pi) or low-Pi medium (0.01 mM Pi). After an additional 3 days, tissues were harvested at the midpoint of the photoperiod.

Subcellular localization of PHT4 fusion proteins

Protein fusion constructs were introduced into leaves of 4-week-old plants by particle bombardment using the Biolistic PDS-1000/He particle delivery system as described previously (Versaw \& Harrison, 2002). After bombardment, leaves were incubated at room temperature on water-saturated filter paper for $24 \mathrm{~h}$ prior to imaging with confocal microscopy. Cells were imaged with a Bio-Rad 1024 ES confocal laser scanning microscope equipped with a 63x (numerical aperture, 1.2) water-immersion objective (488 nm excitation, 522 nm emission for GFP; $568 \mathrm{~nm}$ excitation, $590 \mathrm{~nm}$ emission for RFP, and $488 \mathrm{~nm}$ excitation, $680 \mathrm{~nm}$ emission for chlorophyll autofluorescence. Images shown are single optical sections. 
Quantitative RT-PCR analysis

Total RNA was isolated from leaf and root tissues of 3-week old plants with TRI reagent (Sigma-Aldrich, St. Louis, MO) and traces of DNA were removed with TURBO DNA-free (Ambion, Austin, TX). Two biological replicates consisting of tissues pooled from 3 plants were used for each analysis. One $\mu$ g RNA was used to make cDNA with SuperScript first-strand cDNA synthesis kit (Invitrogen, Carlsbad, CA). PCR was performed with SYBR Green Master Mix (Applied Biosystems, Foster City, CA) using the ABI Prism 7500 sequence detection system (Applied Biosystems). Expression levels were normalized to EIF-4A2 (At1g54270) and fold changes were calculated using the $\Delta \Delta \mathrm{C}_{\mathrm{T}}$ method. The following gene-specific primers were used for real-time PCR: for EIF-4A2, (5'-CAAGGTGTCAAGGTTCATGC-3') and (5'CAACGACAACATGAACACCA-3’); for PHT4;1, (5’-

TCTTCTGGGGTTACCTTCTTACACAGA-3') and (5’TGAGAATTGTAGCGATTGACCACCAA-3’); for PHT4;2, (5’GATGATGCCTGAGAGGATTAAGGTAGT-3’) and (5’TAACAACTCTGTCGGCGTTACATAGA-3’); for PHT4;3, (5’CAGAATTTATAACGTCGGAGAGAGTCAAA-3’) and (5’AAAATGATTTGCTCCATCCACGAGAAAG-3’); for PHT4;4, (5’TGTGAACATGAGCATTGCAATTCTT-3’) and (5’CAACAGTTGCACTACTCCAGTTATATTCT-3’); for PHT4;5, (5’TCCAGTCTTCCTTCTTTTGGGGTTATG-3’) and (5’CGAAAGACCATGTAAAGACACCAATCT-3’); for PHT4;6, (5’- 
GATTGGTTTCGATAACGACATCAGGAA-3') and (5'-

ATTCCGGACCTCTAAGCTCAACTAA-3'); for IPS1, (5’-

AGGGGATGGCCTAAATACAAAATG-3') and (5’-

GGGAGATAAACAAAACTCGCAGTC-3'); and for SQD1, (5'-

CACCACCCGAAACATCTACC-3') and (5'-ACCGCAATAACCATCTCCAC-3').

\section{Results}

Complementation of a yeast Pi transport mutant by PHT4 genes

The Arabidopsis genome contains six genes (Table 1) that encode proteins with similarity to members of the SLC17/type I Pi transporter family, which includes mammalian type I Pi transporters, vesicular glutamate transporters (VGLUTs) and sialin, a lysosomal sialic acid transporter (Reimer \& Edwards, 2004). The Arabidopsis proteins, designated here as PHT4;1 through PHT4;6, have 10-12 putative membrane-spanning domains (Arai et al., 2004), and share 31-76\% similarity with each other and 23-41\% similarity with the human SLC17 members (SLC17A1-8). Multiple anion transport activities have been attributed to members of the SLC17/type I Pi transporter family, e.g. Pi, chloride and glutamate transport (Werner et al., 1991; Debiec \& Ronco, 1993; Ni et al., 1994; Miyamoto et al., 1995; Quabius et al., 1995; Busch et al., 1996; Bröer et al., 1998; Yabuuchi et al., 1998; Verheijen et al., 1999; Aihara et al., 2000; Bellocchio et al., 2000; Takamori et al., 2000; Uchino et al., 2000; Ishibashi et al., 2003; Morin et al., 2004; Juge et al., 2006), but nearly all of the characterized proteins also exhibit $\mathrm{Na}^{+}-$ 
dependent Pi transport (Werner et al., 1991; Debiec \& Ronco, 1993; Ni et al., 1994; Miyamoto et al., 1995; Quabius et al., 1995; Busch et al., 1996; Bröer et al., 1998; Yabuuchi et al., 1998; Aihara et al., 2000; Ishibashi et al., 2003; Juge et al., 2006). Thus, we hypothesized that the similar PHT4 proteins might also have Pi transport functions.

To test this hypothesis, we first used RT-PCR to obtain cDNAs corresponding to the full coding regions of each PHT4 gene, and cloned the amplicons into a yeast expression vector. Multiple splice variants are predicted for some of the PHT4 genes (http://www.arabidopsis.org/); however, we sequenced at least three independent clones for each cDNA and in all cases detected a single form that matched the respective GenBank accession listed in Table 1. We then tested each of the cDNA clones for the ability to complement the growth defect of a yeast Pi transport mutant. The yeast PAM2 strain (Martinez \& Persson, 1998) lacks functional copies of both high-affinity Pi transporter genes present in yeast, $\mathrm{PHO} 4$ and $\mathrm{PHO} 89$, and thus grows poorly when supplied with limiting amounts of Pi. The remaining low affinity transporters (Tamai et al., 1985; Wykoff \& O'Shea, 2001) provide sufficient activity for propagation of this strain under the non-selective conditions. As shown in Fig. 2, all six members of the PHT4 family complemented the growth defect of PAM2 cells, although PHT4;1 was capable of complementation only when the region predicted by ChloroP (Emanuelsson et al., 1999) to encode an $\mathrm{N}$-terminal 59 amino acid transit peptide was deleted. All strains grew equally well when supplied with higher concentrations of Pi. 
TABLE 1. Members of the Arabidopsis PHT4 family

\begin{tabular}{lccc}
\hline Gene & Locus & Former names & Accession \\
\hline PHT4;1 & At2g29650 & P56-2 $^{a}$, ANTR1 $^{b}$ & NM_128519 \\
PHT4;2 & At2g38060 & ANTR3 $^{b}$ & NM_129362 \\
PHT4;3 & At3g46980 & ANTR4 $^{b}$ & NM_114565 \\
PHT4;4 & At4g00370 & P56-4 $^{a}$, ANTR2 $^{b}$ & NM_116261 \\
PHT4;5 & At5g20380 & ANTR6 $^{b}$ & NM_122045 \\
PHT4;6 & At5g44370 & ANTR5 $^{b}$ & NM_123804
\end{tabular}

${ }^{a}$ As described by Ferro et al. (2003), ${ }^{b}$ as described by Roth et al. (2004). 


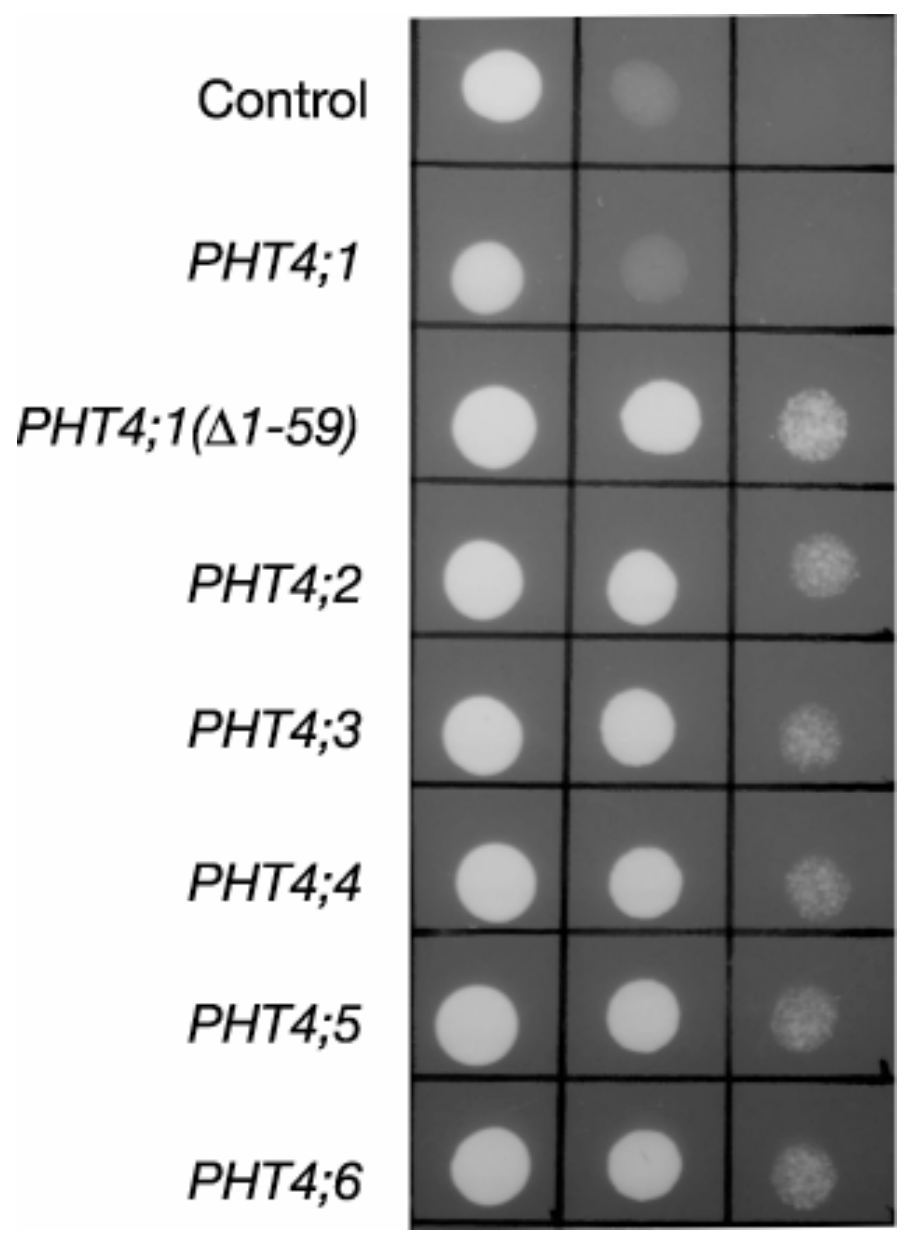

Fig. 2 Complementation of a yeast Pi transport mutant by PHT4 genes. Yeast PAM2 cells harboring either an empty expression vector (control) or the indicated PHT4 cDNA constructs were grown in SD medium containing $0.22 \mathrm{mM}$ Pi at $\mathrm{pH} 4.5$ to an $\mathrm{OD}_{600}=1$, then washed and suspended in water to $\mathrm{OD}_{600}=10$. Equal volumes of 10 -fold serial dilutions were applied to Pi-limiting medium $\left(1 \mathrm{mM}\right.$, $\mathrm{pH}$ 6) then incubated at $30^{\circ} \mathrm{C}$ for 3 days. The PHT4;1(41-59) cDNA lacks the region encoding an N-terminal 59 amino acid putative transit peptide, and a new ATG start codon has been added. 
Analysis of Pi transport activities

${ }^{32} \mathrm{Pi}$ uptake assays were used to confirm and analyze transport mediated by each of the PHT4 proteins expressed in yeast. In all cases, net transport was linear with respect to time for at least 4 minutes (data not shown). Each of the cultures expressing a PHT4 protein displayed saturable Pi transport with initial rates 3 to 4-fold greater than cells carrying the empty expression vector. Because transport velocities were similar, results are shown in Fig. 3 only for the cells exhibiting the highest and lowest activities. To estimate apparent $K_{m}$ values, the component of net transport contributed by the yeast endogenous transport activity (background) was subtracted prior to nonlinear regression analysis. Background activities were determined from concurrent measurements with the control cells. In each case, the apparent $K_{m}$ values were similar for three independent experiments, and ranged from $0.45 \pm 0.08 \mathrm{mM}$ for PHT4;5 to $0.74 \pm 0.06 \mathrm{mM}$ for PHT4;6 (Table 2). These values differ significantly $(\mathrm{P}<0.02)$ from that of the background activity, $0.99 \pm 0.07 \mathrm{mM}$.

Given the broad range of anions transported by some SLC17/type I Pi transporters (Bellocchio et al., 2000; Takamori et al., 2000), we investigated the specificity of PHT4 transporters by testing various anions for the ability to compete with Pi for uptake. Potential inhibitors were added to cells at 10 -fold molar excess to $\mathrm{Pi}$, and the rates of $\mathrm{Pi}$ accumulation were compared to those for cells treated with water. All of the PHT4 transporters appeared highly specific for Pi under these conditions because only arsenate, 


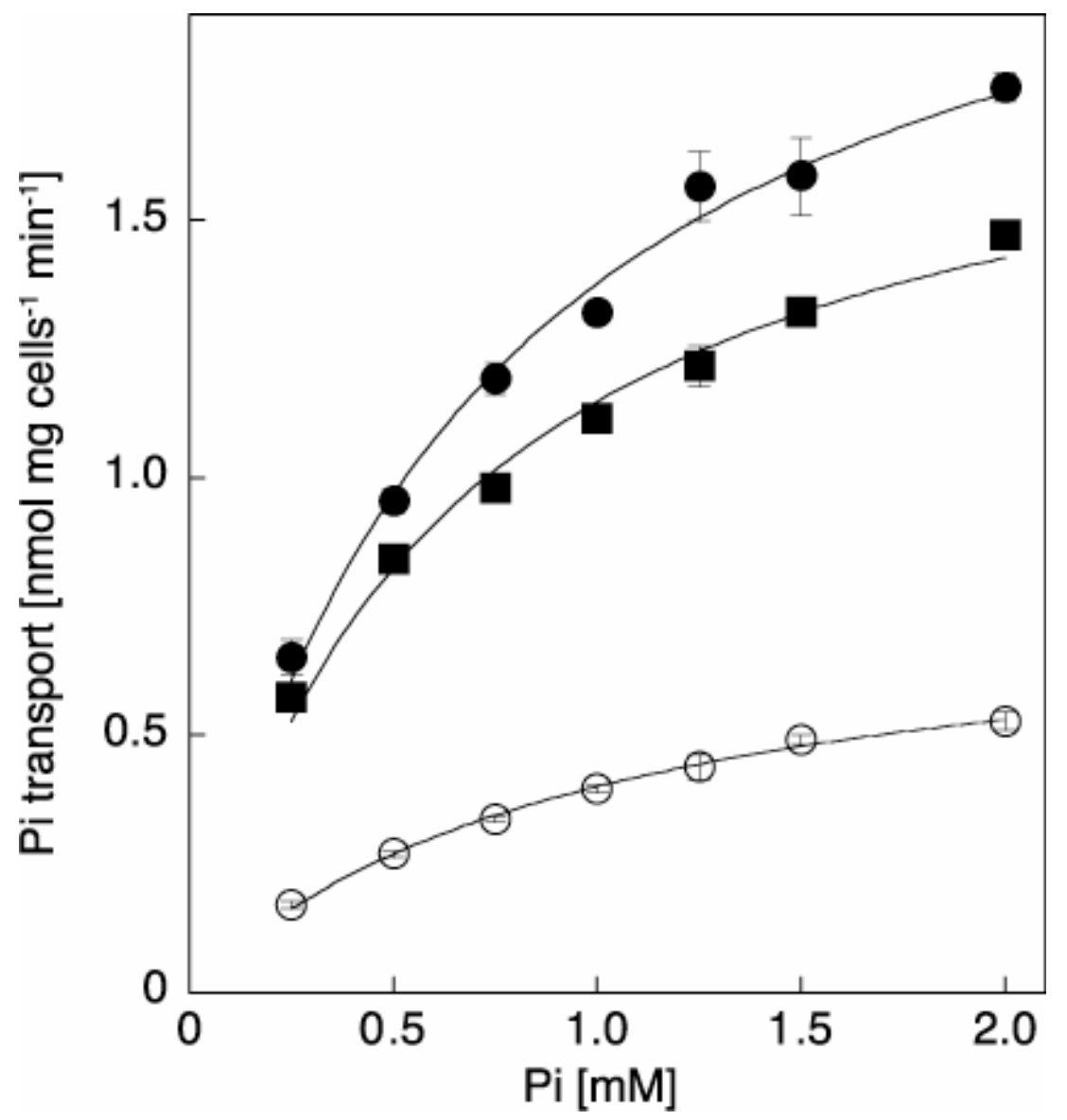

Fig. 3 Kinetics of Pi uptake. Pi uptake rates of yeast PAM2 cells expressing PHT4;1( $\Delta 1$ 59), filled circles; PHT4;2, filled squares; or carrying the vector control, empty circles, were determined with increasing external Pi concentrations, and fitted by nonlinear regression according to the Michaelis-Menten equation. Uptake rates for PAM2 cells expressing the other four PHT4 proteins fall between those of PHT4;1( $\Delta 1-59)$ and PHT4;2. Assays were conducted at $\mathrm{pH} 4$. Values shown are the means $\pm \mathrm{SE}$ for three independent experiments. 
TABLE 2 Apparent $K_{m}$ values for PHT4-mediated Pi transport

\begin{tabular}{lc}
\hline \multicolumn{1}{c}{ Transporter } & Apparent $K_{m}(\mathrm{mM})$ \\
\hline Control & $0.99 \pm 0.07$ \\
PHT4;1( 1 1-59) & $0.66 \pm 0.10$ \\
PHT4;2 & $0.51 \pm 0.08$ \\
PHT4;3 & $0.61 \pm 0.05$ \\
PHT4;4 & $0.72 \pm 0.09$ \\
PHT4;5 & $0.45 \pm 0.08$ \\
PHT4;6 & $0.74 \pm 0.06$
\end{tabular}

Pi uptake rates for yeast strain PAM2 expressing the indicated transporter or carrying the empty expression vector (control) were determined at $\mathrm{pH} 4.0$. Values shown are means \pm SE for 3 independent experiments that consisted of duplicate uptake measurements for 7 substrate concentrations as shown in Fig. 3. 
a structural analog of $\mathrm{Pi}$, caused inhibition at a level approaching that of unlabeled Pi (Table 3). Addition of sulfate and nitrate did result in a slight reduction in Pi transport catalyzed by PHT4;2 but the basis for this inhibition is unknown. We measured the uptake of ${ }^{35} \mathrm{~S}$-sulfate for each of the cultures using essentially the same growth and assay conditions as for $\mathrm{Pi}\left(0.25 \mathrm{mM}^{35} \mathrm{~S}\right.$-sulfate, $\left.\mathrm{pH} 4.0\right)$ but all cultures, including the control, exhibited an equivalent transport rate of $17 \mathrm{pmol} \mathrm{mg} \mathrm{cells}{ }^{-1} \mathrm{~min}^{-1}$. This result suggests that expression of the PHT4 proteins has no general effect on anion permeability of the yeast cells, and that PHT4;2 either does not mediate sulfate transport or does so at a level that is effectively masked by endogenous activities.

Pi transport activities were assessed at $\mathrm{pH}$ values ranging from 3 to 6 , and differences were detected in the activity profiles but in each case, transport was maximal at pH 3 or 4 and declined sharply at pH 6 (Fig. 4). The magnitude of the changes in activity from pH 5 to 6 cannot be explained solely by a preference for the monobasic form of $\mathrm{Pi}$, which would decrease only $8 \%$. Thus, the relatively broad, acidic $\mathrm{pH}$ optima may reflect intrinsic properties of the transporter proteins. Treatment of cells with the protonophore carbonylcyanide $m$-chlorophenylhydrazone (CCCP) caused a significant, concentration-dependent decrease in the rates of Pi transport (Table 3) suggesting that transport may be dependent on the proton-motive force, although secondary effects such as changes in cytosolic $\mathrm{pH}$ may also affect transport activity. Given the similarity of PHT4 proteins to transporters that mediate $\mathrm{Na}^{+}$-dependent Pi transport (Werner et al., 1991; Miyamoto et al., 1995; Busch et al., 1996; Ishibashi et al., 2003), we investigated whether transport might be affected by $\mathrm{Na}^{+}$concentration. Pi transport activities using 
TABLE 3 Specificity and pharmacology of PHT4 transporters

\begin{tabular}{|c|c|c|c|c|c|c|}
\hline \multirow[b]{2}{*}{ Inhibitor } & \multicolumn{6}{|c|}{${ }^{32} \mathrm{Pi}$ uptake activity (\%) } \\
\hline & PHT4;1 & PHT4;2 & PHT4;3 & PHT4;4 & PHT4;5 & PHT4;6 \\
\hline Control & 100 & 100 & 100 & 100 & 100 & 100 \\
\hline Glutamate (2.5 mM) & 100 & 96 & 100 & 100 & 100 & 100 \\
\hline $\mathrm{KCl}(2.5 \mathrm{mM})$ & 100 & 98 & 100 & 100 & 100 & 100 \\
\hline $\mathrm{K}_{2} \mathrm{SO}_{4}(2.5 \mathrm{mM})$ & 100 & 91 & 100 & 100 & 100 & 100 \\
\hline $\mathrm{KNO}_{3}(2.5 \mathrm{mM})$ & 96 & 86 & 100 & 100 & 97 & 98 \\
\hline $\mathrm{Na}_{2} \mathrm{HAsO}_{4}(2.5 \mathrm{mM})$ & 46 & 44 & 46 & 42 & 38 & 41 \\
\hline $\mathrm{Na}_{2} \mathrm{HPO}_{4}(2.5 \mathrm{mM})$ & 34 & 30 & 34 & 37 & 32 & 32 \\
\hline CCCP (0.01 mM) & 74 & 64 & 48 & 57 & 62 & 69 \\
\hline СССР (0.1 mM) & 35 & 42 & 36 & 41 & 35 & 47 \\
\hline
\end{tabular}




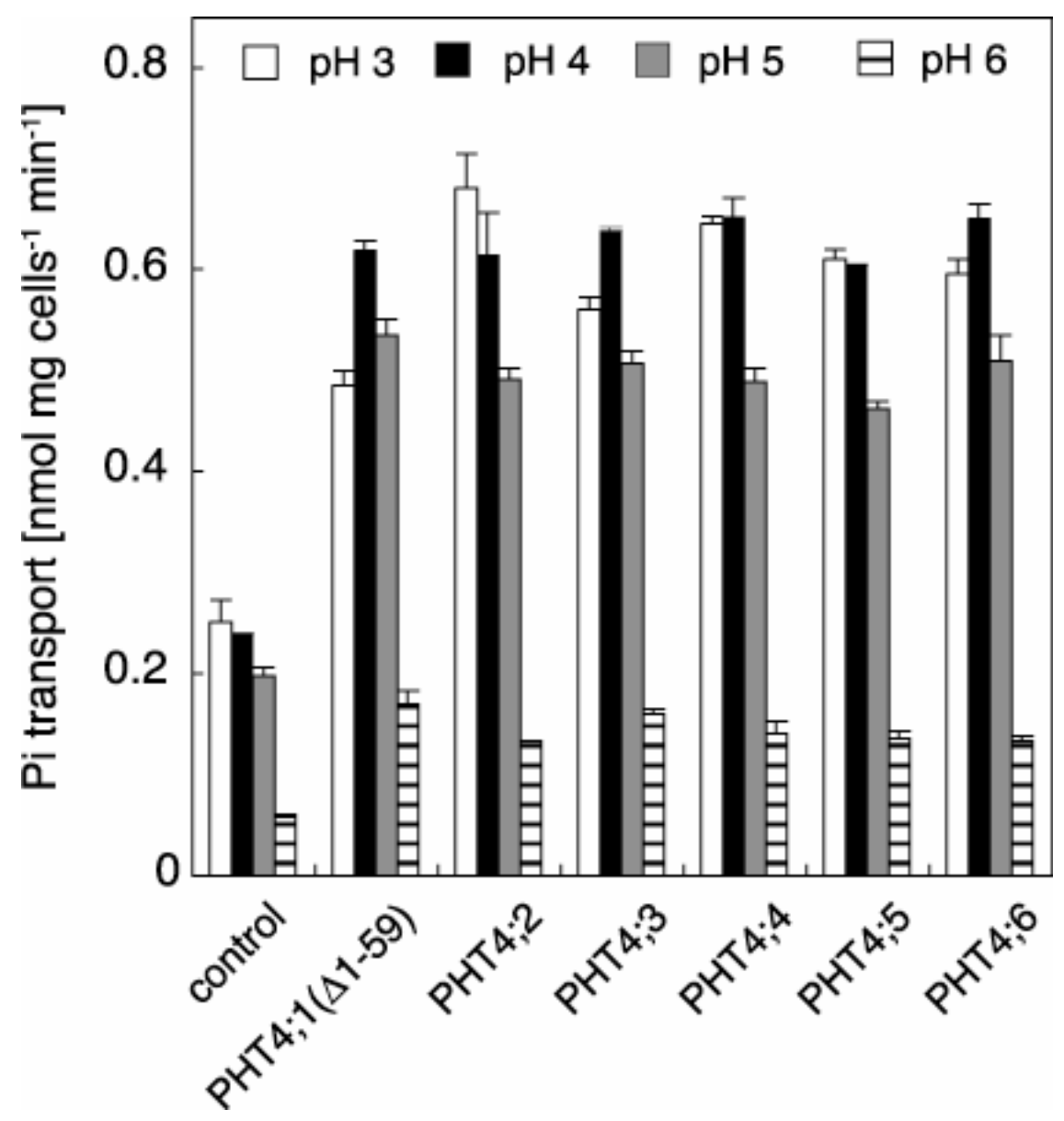

Fig. 4 Pi uptake as a function of external pH. Pi uptake rates for yeast PAM2 cells expressing the indicated PHT4 protein or carrying the control vector were determined at the indicated $\mathrm{pH}$ in medium containing $0.25 \mathrm{mM}$ Pi. Values shown are the means $\pm \mathrm{SE}$ for three independent experiments. 
our standard uptake medium, which contains approximately $30 \mathrm{mM} \mathrm{Na}^{+}$(Versaw \& Harrison, 2002), were compared to those measured in uptake medium in which all of the sodium salts normally present were substituted with potassium salts. Although this concentration of $\mathrm{Na}^{+}$is more than sufficient for maximal activity of the yeast PHO89 $\mathrm{Na}^{+} /$Pi symporter (Martinez \& Persson, 1998), no differences in net transport activities were detected for any of the PHT4 proteins under these conditions (data not shown).

Subcellular localization of PHT4 proteins

The presence of potential organellar targeting sequences located at the $\mathrm{N}$-terminus of each of the PHT4 proteins initially led us to hypothesize that some members of this family would localize to plastids (Versaw \& Harrison, 2002). Consensus subcellular localization predictions derived from 13 different programs (ARAMEMNON database, http://aramemnon.botanik.uni-koeln.de/), suggest that PHT4;1, PHT4;2 and PHT4;3 are located in plastids, and that PHT4;6 is located within the secretory system. The predictions for PHT4;4 and PHT4;5 were ambiguous, with roughly equivalent consensus scores for plastid and mitochondrial localization. This ambiguity was resolved for PHT4;4, and the predictions verified for PHT4;1, through the use of GFP fusions, which confirmed that both of these proteins are located in chloroplasts (Ferro et al., 2003; Roth et al., 2004). Furthermore, Roth et al. (2004) used highly specific antibodies and membrane fractionation to demonstrate that PHT4;4 is located within the chloroplast inner envelope membrane. 
To test the localization predictions for the other members of the PHT4 family, translational fusion constructs were prepared in which the same full-length coding regions used for functional analyses in yeast were cloned downstream of the cauliflower mosaic virus $35 S$ promoter, and fused to the 5' end of GFP. The constructs were introduced into Arabidopsis leaves by particle bombardment and after 24 hrs, the leaves were examined by laser scanning confocal microscopy. The fluorescence images revealed that transiently expressed PHT4;2-GFP and PHT4;5-GFP were localized to chloroplasts, which were distinguished by red chlorophyll autofluorescence (Fig. 5). In contrast, PHT4;6 co-localized with a Golgi marker, rat sialyl transferase transmembranestem region (RatST) fused to RFP (Dixit \& Cyr, 2002). The localization of PHT4;3 remains unresolved because green fluorescence was not detected in leaves bombarded with the PHT4;3-GFP construct, nor a similar truncated fusion containing the first 600 bp of the PHT4;3 coding region. Expression of these fusions in transgenic Arabidopsis also failed to yield detectable GFP signals despite the presence of transcripts, suggesting that the fusion proteins may be unstable.

Expression of PHT4 genes in Arabidopsis

Expression of PHT4 genes in photosynthetic and heterotrophic tissues (rosette leaves and roots, respectively) was analyzed by quantitative RT-PCR. Tissues were harvested from plants grown hydroponically for three weeks, at which time the plants had rosette leaves but no other green tissues. As shown in Fig. 6a, large differences exist 

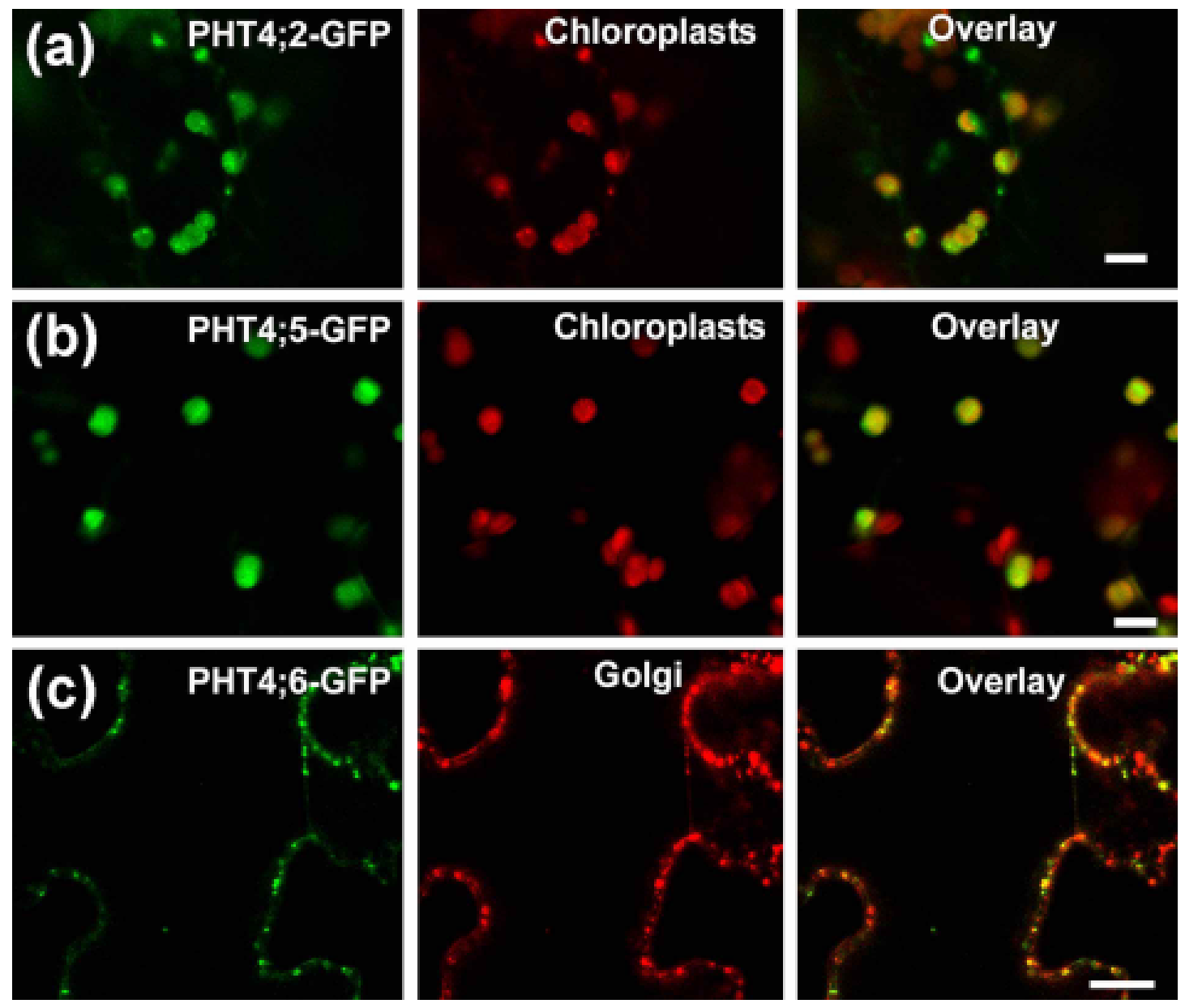

Fig. 5 Subcellular localization of PHT4-GFP fusions. GFP fusion constructs for PHT4;2, PHT4;5 and PHT4;6 were introduced into Arabidopsis leaves by particle bombardment, and the fluorescent signals were examined $24 \mathrm{hr}$ after transformation by confocal microscopy. The green signals indicate GFP, the red signals in rows (a) and (b) indicate chlorophyll autofluorescence, and the red signals in row (c) indicate the Golgi marker RatST-RFP. Bar size in rows (a) and (b) is $10 \mu \mathrm{m}$ and in row (c) it is $20 \mu \mathrm{m}$. 

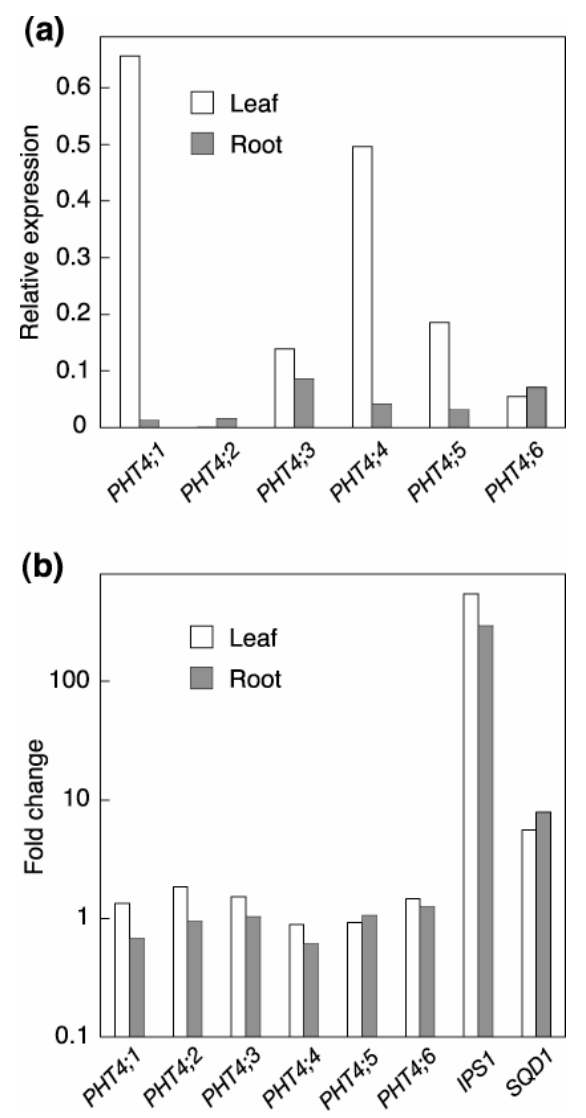

Fig. 6 Quantitative analysis of PHT4 gene expression in Arabidopsis. Real-time RTPCR was conducted using RNA isolated from roots and rosette leaves of two biological replicates, each consisting of tissues pooled from three plants. (a) Expression levels in Pi-replete growth conditions were determined and normalized to EIF-4A2. Values plotted are the averages for the two independent experiments, which yielded $\Delta \mathrm{Ct}$ values that varied no more than 0.5 cycles. (b) Change in relative expression levels after plants were treated to three days of Pi-limiting growth conditions. Values plotted are the average fold change relative to expression in Pi-replete conditions. The Pi-responsive genes, IPS1 and SQD1, are included as positive controls. The $\triangle \mathrm{Ct}$ values for biological replicates varied no more than 0.5 cycles. 
between the PHT4 genes in terms of transcript abundance and specificity for leaves and roots. PHT4; 1 and PHT4;4 displayed the highest levels of expression, both in leaves. With the exception of PHT4;2 and PHT4;6, the other four members of this gene family were expressed more abundantly in leaves than roots. This was most striking for PHT4;1 and PHT4;4, which were expressed 49- and 12-fold greater in leaves than roots, respectively, consistent with their reported chloroplast localization. However, all of the genes exhibited detectable expression in roots, and expression of PHT4;2 was essentially restricted to roots. Hence, the plastid-localized protein members of this family may function in both photosynthetic and heterotrophic plastids, or in the case of PHT4;2, perhaps exclusively in heterotrophic plastids. PHT4;6 was expressed ubiquitously although slightly more strongly in roots than leaves. Despite differences in growth conditions, expression profiles from the Genevestigator microarray databases (Zimmermann et al., 2005) closely match the patterns depicted in Fig. 6a. We also investigated whether transcription of PHT4 genes was influenced by Pi supply. Leaf and root tissues were harvested from plants exposed to Pi-limiting conditions for three days, and the expression levels were compared to those detected under Pi-replete conditions. Results shown in Fig. 6b indicate that this treatment was sufficient to strongly enhance expression of two known Pi-responsive genes, IPS1 and SQD1 (Hammond et al., 2003). However, none of the PHT4 genes exhibited a change in expression greater than 1.8-fold, suggesting that these genes are not responsive to Pi deprivation. 


\section{Discussion}

Our interest in the PHT4 family stemmed from the possibility that the Pi transport function exhibited by structurally related animal proteins, which comprise the SLC17/type I Pi transporter family, might be conserved in plants. Although previous studies confirmed plastid localization of PHT4;1 and PHT4;4 (Ferro et al., 2003; Roth et al., 2004), and a spinach homolog of PHT4;4 was identified from analysis of the chloroplast envelope proteome (Ferro et al., 2003), no biochemical function was determined for these proteins. The animal homologs exhibit transport activities for $\mathrm{Pi}$, chloride and a wide range of organic anions (Werner et al., 1991; Debiec \& Ronco, 1993; Ni et al., 1994; Miyamoto et al., 1995; Quabius et al., 1995; Busch et al., 1996; Bröer et al., 1998; Yabuuchi et al., 1998; Verheijen et al., 1999; Aihara et al., 2000; Bellocchio et al., 2000; Takamori et al., 2000; Uchino et al., 2000; Ishibashi et al., 2003; Morin et al., 2004; Juge et al., 2006), but it has been proposed that organic anion transport is their primary function (Reimer \& Edwards, 2004). However, biochemical studies have revealed that most of these proteins also mediate Pi transport (Werner et al., 1991; Debiec \& Ronco, 1993; Ni et al., 1994; Miyamoto et al., 1995; Quabius et al., 1995; Busch et al., 1996; Bröer et al., 1998; Yabuuchi et al., 1998; Aihara et al., 2000; Ishibashi et al., 2003; Juge et al., 2006). To determine if conservation of the Pi transport function extends to plant homologs, we expressed each of the PHT4 proteins in a yeast Pi uptake defective mutant. Complementation of the growth defect of this mutant under limiting Pi conditions, and uptake assays using radiolabeled Pi, demonstrated that all of 
the PHT4 proteins are indeed capable of mediating Pi transport. Transport was inhibited by competition with arsenate, a structural analog of Pi, but not glutamate, chloride, sulfate or nitrate, indicating specificity for Pi. Although it was formally possible that the transport activities attributed to the PHT4 proteins reflect a direct or indirect upregulation of an endogenous yeast Pi transporter rather than innate functions, this idea is not consistent with transport kinetics in which the apparent $K_{m}$ values for the PHT4mediated and background transport activities differed significantly. Therefore, we conclude that a Pi transport function is associated with each PHT4 protein. Although apparent $K_{m}$ values determined from expression in yeast need not reflect those in planta (Leggewie et al., 1997; Mitsukawa et al., 1997; Daram et al., 1998), the similar, low affinities for Pi displayed by the PHT4 transporters are consistent with the relatively high Pi concentrations expected within the cytosol and other subcellular compartments (Dietz \& Heber, 1984; Sharkey \& Vanderveer, 1989; Mimura, 1999).

Our functional assay relied on Pi transport across the yeast plasma membrane. However, the efficiency with which plastid membrane proteins localize to the plasma membrane of fungal cells rather than internal membranes appears to be primarily a function of the transit peptide sequences (Brink et al., 1994; Versaw \& Harrison, 2002; Zhao et al., 2003; Drummond et al., 2006; Seigneurin-Berny et al., 2006; Duy et al., 2007). Therefore, it was not surprising that the PHT4;1 protein was unable to complement the PAM2 mutant unless the predicted transit peptide was removed. Yeast expression studies with an unrelated plastid-localized Pi transporter, PHT2;1, revealed that removal of the transit peptide resulted in a shift in location from mitochondria to the 
plasma membrane, and this shift was associated with a large increase in transport activity (Versaw \& Harrison, 2002). Thus, it is likely that the full-length PHT4;1 protein is sequestered in an internal compartment whereas the truncated protein is at least partially localized to the plasma membrane. Removal of the non-conserved, $\mathrm{N}$-terminal targeting sequences from the other PHT4 proteins was not necessary to assess transport function, which suggests that these sequences are not recognized by the same yeast trafficking machinery. These results differ from those reported by Roth et al. (2004) in which expression of PHT4;1 and PHT4;4 with or without transit peptides in yeast failed to yield detectable transport activities. Given that we also failed to detect consistent transport activities when cells were grown in rich media or were grown to high densities, it is possible that the growth conditions described here (low Pi concentration and low culture density) favor retention of the transporters in the plasma membrane and/or folding of the proteins into active conformations.

Transiently expressed GFP protein fusions revealed that, like PHT4;1 and PHT4;4, PHT4;2 and PHT4;5 are also located in plastids. Although we were unable to verify the subcellular location of PHT4;3, computer-based predictions suggest that it too is targeted to plastids. Assuming that this prediction is accurate, five of the six members of this family (PHT4;1 through PHT4;5) localize to the plastid envelope. PHT4;1, PHT4;3, PHT4;4 and PHT4;5 display greater expression in leaves than roots, which suggests that the encoded proteins may function primarily in the chloroplast. However, all five of the genes are expressed at detectable levels in roots, suggesting that the proteins are also targeted to heterotrophic plastids. In contrast, a PHT4;6-GFP fusion protein co-localized 
with a Golgi marker, which is consistent with the SignalP prediction (Emanuelsson et al., 2000) that PHT4;6 possesses an N-terminal signal peptide. Because several of the PHT4 proteins, as well as unrelated Pi transporters, may have overlapping or redundant functions in the same organelle, the inactivation of multiple transporter genes may be required to determine the physiological role of individual transporters.

It is tempting to speculate that the direction of Pi transport mediated by PHT4 proteins in yeast is the same in plastids and the Golgi of the plant cell, i.e., transport from the non-cytosolic side of a membrane to the cytosol (export from the plastid stroma and Golgi lumen). However, the direction of Pi transport across a given membrane is expected to be a function of the proton-motive force and Pi electrochemical gradient rather than being strictly dependent on orientation relative to the cytosol. This is supported by the Arabidopsis chloroplast inner envelope-localized transporter, PIC1, which facilitates uptake of iron across the plasma membrane when expressed in yeast, but mediates transport from the cytosol to the chloroplast stroma in the plant, and in both locations, transport appears to be energized by a proton gradient (Shingles et al., 2002; Duy et al., 2007). Consequently, we hypothesize that Pi transport mediated by PHT4 proteins in planta is dependent, at least in part, on subcellular proton gradients. Furthermore, it is possible that protons serve as a co-transported substrate, but this has not been demonstrated directly.

The $\mathrm{pH}$ of only some of the intracellular compartments relevant to PHT4 proteins has been determined. The cytosolic $\mathrm{pH}$ is near neutral, the $\mathrm{pH}$ of the chloroplast stroma increases from 7 to 8 in response to light (Heldt et al., 1973), and the Golgi pH is about 
6.5 (Llopis et al., 1998). The magnitudes of these $\mathrm{pH}$ gradients are modest, but this does not preclude the possibility that they are sufficient to facilitate transport of Pi between cellular compartments, especially given that Pi concentrations in the cytosol and the respective organelles may differ by less than 10-fold (Dietz \& Heber, 1984; Sharkey \& Vanderveer, 1989; Mimura, 1999). These pH gradients would be expected to favor transport of Pi from the cytosol to the chloroplast stroma, and with export from the Golgi, both of which are consistent with known transport activities (Neckelmann \& Orellana, 1998; Flügge, 1999).

Our results provide the first evidence for the biochemical function of PHT4 proteins. Based on the subcellular location of these proteins in chloroplasts, heterotrophic plastids and the Golgi apparatus, we suggest that these transporters represent candidates for, or participate in, some of the known, but poorly understood, Pi transport activities in the plant cell (Neuhaus \& Maass, 1996; Neckelmann \& Orellana, 1998). 


\section{CHAPTER III}

\section{CONCLUSIONS AND PERSPECTIVES}

The work described in this thesis provides compelling evidence that the Arabidopsis PHT4 proteins comprise a novel plant Pi transporter family, and that the individual proteins function in either chloroplasts, heterotrophic plastids or in the Golgi apparatus. These findings provide new insight and tools with which to explore how plants coordinate metabolic processes in different subcellular compartments to support growth and development.

Efforts to determine the physiological roles of individual PHT4 proteins have been initiated by me and by the other members of the lab, and these are ongoing. My efforts have focused on determining the tissue and cell specificity of each PHT4 gene. For the five members of this gene family that encode plastid-targeted proteins (PHT4;1 through PHT4;5), expression in leaves and roots suggests potential roles in chloroplasts and heterotrophic plastids, respectively. PHT4 promoters (0.6-1.6 kb regions) were amplified and cloned in the binary vector pBI101.1 upstream of the $\beta$-glucuronidase (GUS) gene to generate transcriptional fusions. These reporter constructs were introduced into Arabidopsis, and transgenic plants were assayed for GUS activity. These analyses have yielded interesting, and in some cases, unexpected results.

PHT4;1 and PHT4;4 promoters conferred nearly identical GUS expression patterns, which were largely consistent with their localization to chloroplasts. Reporter activity was detected throughout the green tissues of seedlings (Fig. 7a) and in sepals of mature 
flowers (Fig. 7c). In rosette leaf sections, GUS activity appeared to be present in all cell types but was not uniformly distributed in the epidermis (Fig. 7i). To examine expression in epidermal cells more directly, leaf epidermal peels were isolated then stained for reporter activity. GUS expression was detected only in guard and subsidiary cells (Fig. 7j). In all cases, red autofluorescence indicative of chlorophyll co-localized with GUS activity in the epidermis (Fig. 7k), suggesting that PHT4;1 and PHT4;4 are expressed predominantly in photosynthetic cells. Low levels of GUS activity were also detected in the root cortex of seedlings containing the PHT4;1 promoter-GUS fusion (Fig. 7g), suggesting that PHT4;1 may also function in a subset of heterotrophic cells. No reporter activity was detected in roots of plants that contained the PHT4;4 promoterGUS fusion. Since PHT4;4 transcripts can be detected in roots by RT-PCR (Fig. 6), it is likely that PHT4;4 promoter activity in roots was below the limit of detection for the GUS histochemical assay. If true, PHT4;1 and PHT4;4 may have identical cell specificities. The primary role of these transporters may be to supply Pi to the chloroplast when metabolic demand, i.e., photosynthesis, cannot be met by TPT alone.

Consistent with our RT-PCR analysis (Fig. 6), GUS expression driven by the PHT4;2 promoter was detected throughout the root tissue but was absent from leaves (Fig. 7b). These data suggest that PHT4;2 is predominantly, if not exclusively, localized to heterotrophic root plastids. PHT4;2 may participate in the maintenance of stromal Pi homeostasis during starch synthesis (Neuhaus \& Maass, 1996).

RT-PCR analysis (Fig. 6) indicated that PHT4;3 and PHT4;5 transcripts are more abundant in leaves than roots. This is essentially the same pattern exhibited by 

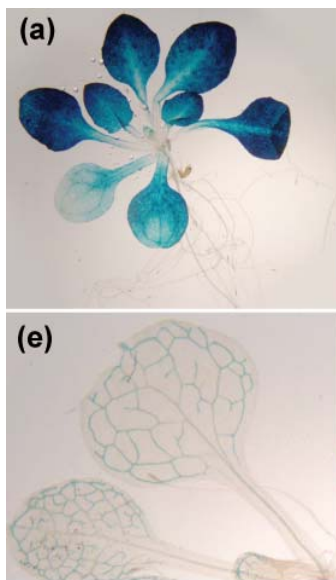

(i)

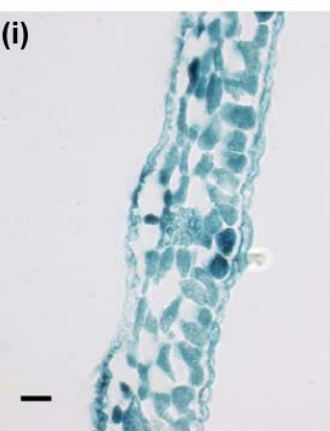

(b)

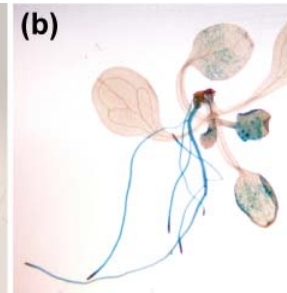

(f)
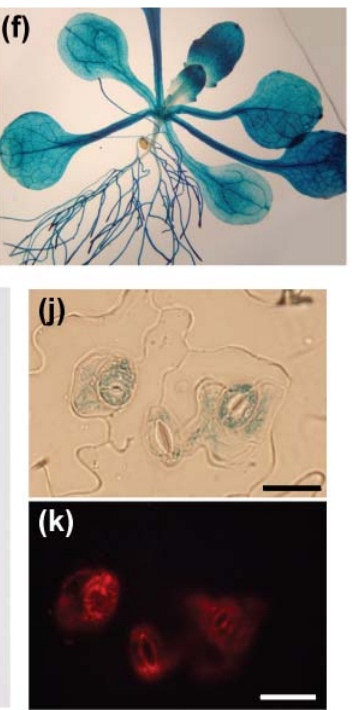

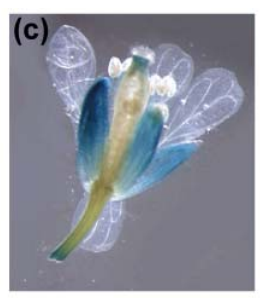

(g)
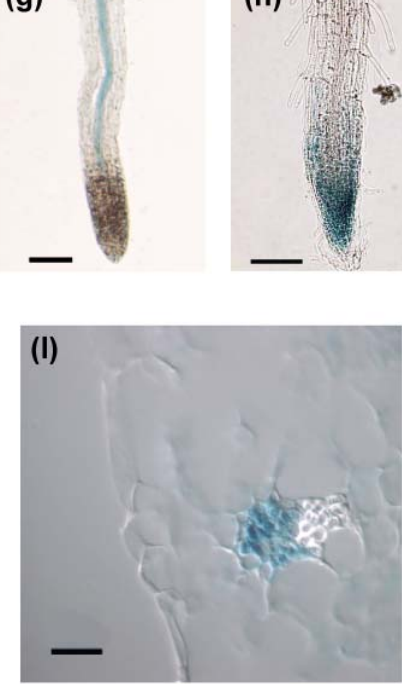

(h)

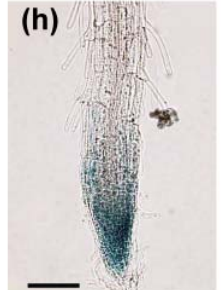

$\$$

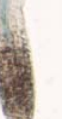

(d)

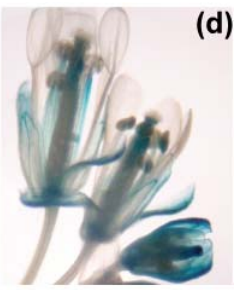

$$
\text { . }
$$

\section{(1)}

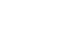
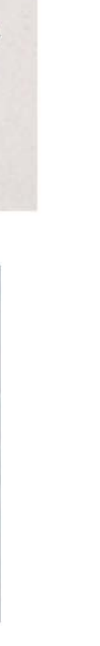

Fig 7. Localization of promoter-GUS gene fusions in transgenic A. thaliana plants. In transgenic seedlings, PHT4;1 and PHT4;4 are expressed in leaves (a); PHT4;2 is expressed in roots (b); PHT4;3 and PHT4;5 are expressed in leaf vascular tissue (e) and PHT4;6 is expressed throughout the seedling (f). In transgenic flowers: PHT4;1, PHT4;4 and PHT4;5 are expressed in sepals (c) and PHT4;6 is expressed in in sepals, stamens and carpels (d). In roots, PHT4;1 is expressed in the center of the root (g). PHT4;3 is expressed in the root cap (h). PHT4;1 is expressed in most cells in a leaf cross section (i) and in photosynthetic cells of a leaf epidermal peel: transmitted bright field (j), epifluorescence showing chlorophyll auto-fluorescence (k). PHT4;3 and PHT4;5 are expressed in phloem tissue in a leaf cross section (l). Nomarski prism was engaged to show differential refraction of xylem. Scale bars are $20 \mu \mathrm{m}$ in g-l. 
PHT4;1 and PHT4;4, but with lower relative transcript levels in leaves. Thus, it was surprising to find that GUS activities in plants harboring the PHT4;3- and PHT4;5-GUS fusions were restricted to the vascular tissues of leaves and cotyledons (Fig. 7e). Sections of GUS stained leaves from these plants revealed that PHT4;3 and PHT4;5 promoters are both specifically active in phloem tissue (Fig. 7l), which suggests that the encoded proteins function in a distinct plastid type. Little has been reported on the metabolic functions of phloem plastids, although they appear to be heterotrophic and accumulate either starch or protein (Behnke, 1991), and may be the primary sites of tryptophan biosynthesis (Lu \& McKnight, 1999).

The PHT4;6 promoter directed GUS activity throughout transgenic seedlings (Fig. 7f), as well as sepals, stamens and carpels of mature flowers (Fig. 7d). PHT4;6 is targeted to the Golgi apparatus, and this transporter may participate in Pi efflux from this organelle, which is required to sustain protein and lipid glycosylation (Neckelmann \& Orellana, 1998).

Null mutants for all of the PHT4 genes except PHT4;3 have been identified and are under investigation in our lab. Results from the promoter-GUS analyses described above provide insight to the potential roles of each transporter, and provide a rationale for combining mutations if phenotypes are not readily detected in single mutants. These mutants will help determine the roles for PHT4 proteins in photosynthesis, starch accumulation and the control of plant-wide nutrient allocation. 


\section{REFERENCES}

\section{Aihara Y, Mashima H, Onda H, Hisano S, Kasuya H, Hori T, Yamada S, Tomura} H, Yamada Y, Inoue I, Kojima I, Takeda J. 2000. Molecular cloning of a novel brain-type $\mathrm{Na}^{+}$-dependent inorganic phosphate cotransporter. Journal of Neurochemistry 74(6): 2622-2625.

Arai M, Mitsuke H, Ikeda M, Xia JX, Kikuchi T, Satake M, Shimizu T. 2004. Conpred II: A consensus prediction method for obtaining transmembrane topology models with high reliability. Nucleic Acids Research 32(Web Server issue): W390-393.

Bannai H, Tamada Y, Maruyama O, Nakai K, Miyano S. 2002. Extensive feature detection of n-teminal protein sorting signals. Bioinformatics 18(2): 298-305.

Behnke HD. 1991. Distribution and evolution of forms and types of sieve-element plastids in the dicotyledons. Aliso 3: 167-182.

Bellocchio EE, Reimer RJ, Fremeau RT, Edwards RH. 2000. Uptake of glutamate into synaptic vesicles by an inorganic phosphate transporter. Science 289: 957960.

Brink S, Flügge UI, Chaumont F, Boutry M, Emmermann M, Schmitz U, Becker K, Pfanner N. 1994. Preproteins of chloroplast envelope inner membrane contain targeting information for receptor-dependent import into fungal mitochondria. Journal of Biological Chemistry 269(23): 16478-16485. 
Bröer S, Schuster A, Wagner CA, Bröer A, Forster I, Biber J, Murer H, Werner A, Lang F, Busch AE. 1998. Chloride conductance and Pi transport are separate functions induced by the expression of Napi-1 in Xenopus oocytes. Journal of Membrane Biology 164(1): 71-77.

Bucher M, Rausch C, Daram P. 2001. Molecular and biochemical mechanisms of phosphorus uptake into plants. Journal of Plant Nutrition and Soil Science 164: 209-217.

Bun-Ya M, Nishimura M, Harashima S, Oshima Y. 1991. The PHO84 gene of Saccharomyces cerevisiae encodes an inorganic phosphate transporter. Molecular and Cellular Biology 11(6): 3229-3238.

Busch AE, Schuster A, Waldegger S, Wagner CA, Zempel G, Broer S, Biber J, Murer H, Lang F. 1996. Expression of a renal type I sodium/phosphate transporter (Napi-1) induces a conductance in Xenopus oocytes permeable for organic and inorganic anions. Proceedings of the National Academy of Sciences, USA 93(11): 5347-5351.

Chiu W, Niwa Y, Zeng W, Hirano T, Kobayashi H, Sheen J. 1996. Engineered GFP as a vital reporter in plants. Current Biology 6(3): 325-330.

Daram P, Brunner S, Persson BL, Amrhein N, Bucher M. 1998. Functional analysis and cell-specific expression of a phosphate transporter from tomato. Planta 206: 225-233. 
Daram P, Brunner S, Rausch C, Steiner C, Amrhein N, Bucher M. 1999. Pht2;1 encodes a low-affinity phosphate transporter from Arabidopsis. Plant Cell 11: 2153-2166.

Debiec H, Ronco PM. 1993. Identification and epitope analysis of the renal $\mathrm{Na}^{+} / \mathrm{Pi}$ cotransport protein using monoclonal antibodies. Journal of Biological Chemistry 268(18): 13356-13363.

Dixit R, Cyr R. 2002. Golgi secretion is not required for marking the preprophase band site in cultured tobacco cells. Plant Journal 29(1): 99-108.

Drummond RSM, Tutone A, Li YC, Gardner RC. 2006. A putative magnesium transporter AtMRS2-11 is localized to the plant chloroplast envelope membrane system. Plant Science 170: 78-89.

Duy D, Wanner G, Meda AR, von Wiren N, Soll J, Philippar K. 2007. PIC1, an ancient permease in Arabidopsis chloroplasts, mediates iron transport. Plant Cell 19(3): 986-1006.

Emanuelsson O, Nielsen H, Brunak S, von Heijne G. 2000. Predicting subcellular localization of proteins based on their N-terminal amino acid sequence. Journal of Molecular Biology 300(4): 1005-1016.

Emanuelsson O, Nielsen H, von Heijne G. 1999. ChloroP, a neural network-based method for predicting chloroplast transit peptides and their cleavage sites. Protein Science 8(5): 978-984. 
Ferro M, Salvi D, Brugiere S, Miras S, Kowalski S, Louwagie M, Garin J, Joyard J, Rolland N. 2003. Proteomics of the chloroplast envelope membranes from Arabidopsis thaliana. Molecular and Cellular Proteomics 2(5): 325-345.

Ferro M, Salvi D, Riviere-Rolland H, Vermat T, Seigneurin-Berny D, Grunwald D, Garin J, Joyard J, Rolland N. 2002. Integral membrane proteins of the chloroplast envelope: Identification and subcellular localization of new transporters. Proceedings of the National Academy of Sciences, USA 99(17): 11487-11492.

Flügge U. 1999. Phosphate translocators in plastids. Annual Review of Plant Physiology and Plant Molecular Biology 50: 27-45.

Flügge UI, Fischer K, Gross A, Sebald W, Lottspeich F, Eckerskorn C. 1989. The triose phosphate-3-phosphoglycerate-phosphate translocator from spinach chloroplasts: Nucleotide sequence of a full-length cDNA clone and import of the in vitro synthesized precursor protein into chloroplasts. EMBO Journal. 8(1): 3946.

Hamel P, Saint-Georges Y, de Pinto B, Lachacinski N, Altamura N, Dujardin G 2004. Redundancy in the function of mitochondrial phosphate transport in Saccharomyces cerevisiae and Arabidopsis thaliana. Molecular Microbiology. 51(2): 307-317.

Hammond JP, Bennett MJ, Bowen HC, Broadley MR, Eastwood DC, May ST, Rahn C, Swarup R, Woolaway KE, White PJ. 2003. Changes in gene 
expression in Arabidopsis shoots during phosphate starvation and the potential for developing smart plants. Plant Physiology 132(2): 578-596.

Heldt HW, Werdan K, Milovancev M, Geller G. 1973. Alkalinization of the chloroplast stroma caused by light-dependent proton flux in the thylakoid space. Biochimica et Biophysica Acta 314: 224-241.

Ishibashi K, Matsuzaki T, Takata K, Imai M. 2003. Identification of a new member of type I Na/phosphate co-transporter in the Rat kidney. Nephron Physiology 94: $10-18$.

Juge N, Yoshida Y, Yatsushiro S, Omote H, Moriyama Y. 2006. Vesicular glutamate transporter contains two independent transport machineries. Journal of Biological Chemistry 281(51): 39499-39506.

Kai M, Masuda Y, Kikuchi Y, Osaki M, Tadano T. 1997. Isolation and characterization of a cDNA from Catharanthus roseus which is highly homologous with phosphate transporter. Soil Science Plant Nutrition 43: 227-235.

Kiiskinen M, Korhonen M, Kangasjarvi J. 1997. Isolation and characterization of cDNA for a plant mitochondrial phosphate translocator (Mpt1): Ozone stress induces Mpt1 mRNA accumulation in birch (Betula pendula Roth). Plant Molecular Biology 35(3): 271-279.

Knappe S, Flügge UI, Fischer K. 2003. Analysis of the plastidic phosphate translocator gene family in Arabidopsis and identification of new phosphate translocatorhomologous transporters, classified by their putative substrate-binding site. Plant Physiology 131: 1178-1190. 
Leggewie G, Willmitzer L, Riesmeier JW. 1997. Two cDNAs from potato are able to complement a phosphate uptake-deficient yeast mutant: identification of phosphate transporters from higher plants. Plant Cell 9: 381-392.

Liu C, Muchhal US, Uthappa M, Kononowicz AK, Raghothama KG. 1998. Tomato phosphate transporter genes are differentially regulated in plant tissues by phosphorus. Plant Physiology 116: 91-99.

Liu H, Trieu AT, Blaylock LA, Harrison MJ. 1998. Cloning and characterization of two phosphate transporters from Medicago truncatula roots: Regulation in response to phosphate and to colonization by arbuscular mycorrhizal (AM) fungi. Molecular Plant-Microbe Interactions 11(1): 14-22.

Llopis J, McCaffery JM, Miyawaki A, Farquhar MG, Tsien RY. 1998. Measurement of cytosolic, mitochondrial, and golgi $\mathrm{pH}$ in single living cells with green fluorescent proteins. Proceedings of the National Academy of Sciences, USA 95: 6803-6808.

Marschner H. 1995. Mineral Nutrition of Higher Plants. London: London Academic Press.

Martinez P, Persson BL. 1998. Identification, cloning and characterization of a derepressible $\mathrm{Na}^{+}$-coupled phosphate transporter in Saccharomyces cerevisiae. Molecular and General Genetics 258: 628-638.

Massonneau A, Martinola E, Dietz KJ, Mimura T. 2000. Phosphate uptake across the tonoplast of intact vacuoles isolated from suspension-cultured cells of Cantharanthus Roseus (L.) G. Don. Planta 211: 390-395. 
Mimura T. 1999. Regulation of phosphate transport and homeostasis in plant cells. International Review of Cytology 191: 149-200.

Mitsukawa N, Okumura S, Shirano Y, Sato S, Kato T, Harashima S, Shibata D. 1997. Overexpression of an Arabidopsis thaliana high-affinity phosphate transporter gene in tobacco cultured cells enhances cell growth under phosphatelimited conditions. Proceedings of the National Academy of Sciences, USA 94: 7098-7102.

Miyamoto K, Tatsumi S, Sonoda T, Yamamoto H, Minami H, Taketani Y, Takeda E. 1995. Cloning and functional expression of a $\mathrm{Na}(+)$-dependent phosphate cotransporter from human kidney: cDNA cloning and functional expression. Biochemical Journal 305: 81-85.

Morin P, Sagne C, Gasnier B. 2004. Functional characterization of wild-type and mutant human Sialin. EMBO Journal 23(23): 4560-4570.

Muchhal US, Pardo JM, Raghathama KG. 1996. Phosphate transporters from the higher plant Arabidopsis thaliana. Proceedings of the National Academy of Sciences, USA 93: 101519-110523.

Mudge SR, Rae AL, Diatloff E, Smith F.W. 2002. Expression analysis suggests novel roles for members of the Pht1 family of phosphate transporters in Arabidopsis. Plant Journal 31(3): 341-353.

Murashige T, Skoog F. 1962. A revised medium for rapid growth and bioassays with tobacco tissue cultures. Physiologia Plantarum 15: 473-497. 
Nakai K, Kanehisa M. 1991. Expert system for predicting protein localization sites in gram-negative bacteria. Proteins: Structure, Function, and Genetics 11: 95-110.

Neckelmann G, Orellana A. 1998. Metabolism of uridine 5'-diphosphate-glucose in Golgi vesicles from pea stems. Plant Physiology 117: 1007-1014.

Neuhaus HE, Emes MJ. 2000. Nonphotosynthetic metabolism in plastids. Annual Review of Plant Physiology and Plant Molecular Biology 51: 111-140.

Neuhaus HE, Maass U. 1996. Unidirectional transport of orthophosphate across the envelope of isolated Cauliflower-bud amyloplasts. Planta 198: 542-548.

Ni B, Rosteck PR, Jr., Nadi NS, Paul SM. 1994. Cloning and expression of a cDNA encoding a brain-specific $\mathrm{Na}(+)$-dependent inorganic phosphate cotransporter. Proceedings of the National Academy of Sciences, USA 91(12): 5607-5611.

Okumura S, Mitsukawa N, Shirano Y, Shibata D. 1998. Phosphate transporter gene family of Arabidopsis thaliana. DNA Research 5: 261-269.

Plaxton WC, Carswell MC 1999. Metabolic aspects of the phosphate starvation response in plants. In: Lerner HR, ed. Plant Responses to Environmental Stresses: From Phytohormones to Genome Reorganization. New York: M. Dekker, 350372.

Poirier Y, Bucher M 2002. Phosphate transport and homeostasis in Arabidopsis. In: Somerville CR, Meyerowitz EM, eds. The Arabidopsis Book. Rockville, MD: American Society of Plant Biologists, 1-35. 
Quabius ES, Murer H, Biber J. 1995. Expression of a renal Na/Pi cotransporter (Napi1) in MDCK and LLC-PK1 cells. Pflügers Archives-European Journal of Physiology 430(1): 132-136.

Raghothama K. 1999. Phosphate acquisition. Annual Review of Plant Physiology and Plant Molecular Biology 50: 665-693.

Rausch C, Bucher M. 2002. Molecular mechanisms of phosphate transport in plants. Planta 216: 23-37.

Rausch C, Zimmermann P, Amrhein N, Bucher M. 2004. Expression analysis suggests novel roles for the plastidic phosphate transporter Pht2;1 in auto- and heterotrophic tissues in potato and Arabidopsis. Plant Journal 39(1): 13-28.

Reimer RJ, Edwards RH. 2004. Organic anion transport is the primary function of the SLC17/type I phosphate transporter family. Pflügers Archives-European Journal of Physiology 447(5): 629-635.

Roth C, Menzel G, Petetot JM, Rochat-Hacker S, Poirier Y. 2004. Characterization of a protein of the plastid inner envelope having homology to animal inorganic phosphate, chloride and organic-anion transporters. Planta 218(3): 406-416.

Schachtman DP, Reid RJ, Ayling SM. 1998. Phosphorus uptake by plants: From soil to cell. Plant Physiology 116: 447-453.

Schwacke R, Schneider A, van der Graaff E, Fischer K, Catoni E, Desimone M, Frommer WB, Flügge UI, Kunze R. 2003. Aramemnon, a novel database for Arabidopsis integral membrane proteins. Plant Physiology 131(1): 16-26. 
Seigneurin-Berny D, Gravot A, Auroy P, Mazard C, Kraut A, Finazzi G, Grunwald D, Rappaport F, Vavasseur A, Joyard J, Richaud P, Rolland N. 2006. HMA1, a new $\mathrm{Cu}$-ATPase of the chloroplast envelope, is essential for growth under adverse light conditions. Journal of Biological Chemistry 281(5): 2882-2892.

Sharkey TD, Vanderveer PJ. 1989. Stromal phosphate concentration is low during feedback limited photosynthesis. Plant Physiology 91(2): 679-684.

Shingles R, North M, McCarty RE. 2002. Ferrous ion transport across chloroplast inner envelope membranes. Plant Physiology 128: 1022.

Smith FW, Cybinski DH, Rae AL 1999. Regulation of expression of genes encoding phosphate transporters in barley roots. In: G. Gissel-NeilsenA. Jensen eds. Plant nutrition - molecular biology and genetics. Proceedings of the sixth international symposium on genetics and molecular biology of plant nutrition. Elsinore, Denmark: Dordrecht, The Netherlands: Kluwer Academic Publishers.

Smith FW, Ealing PM, Dong B, Delhaize E. 1997. The cloning of two Arabidopsis genes belonging to a phosphate transporter family. Plant Journal 11(1): 83-92.

Takamori S, Rhee JS, Rosenmund C, Jahn R. 2000. Identification of a vesicular glutamate transporter that defines a glutamatergic phenotype in neurons. Nature 407(6801): 189-194.

Tamai Y, Toh-e A, Oshima Y. 1985. Regulation of inorganic phosphate transport systems in Saccharomyces Cerevisiae. Journal of Bacteriology 164: 964-968.

Tocquin P, Corbesier L, Havelange A, Pieltain A, Kurtem E, Bernier G, Perilleux C. 2003. A novel high efficiency, low maintenance, hydroponic system for 
synchronous growth and flowering of Arabidopsis thaliana. BMC Plant Biology 3: 2.

Uchino H, Tamai I, Yamashita K, Minemoto Y, Sai Y, Yabuuchi H, Miyamoto K, Takeda E, Tsuji A. 2000. p-Aminohippuric acid transport at renal apical membrane mediated by human inorganic phosphate transporter Npt1. Biochemical and Biophysical Research Communications 270(1): 254-259.

Verheijen FW, Verbeek E, Aula N, Beerens CE, Havelaar AC, Joosse M, Peltonen L, Aula P, Galjaard H, van der Spek PJ, Mancini GM. 1999. A new gene, encoding an anion transporter, is mutated in sialic acid storage diseases. Nature Genetics 23(4): 462-465.

Versaw WK, Harrison MJ. 2002. A chloroplast phosphate transporter, PHT2;1, influences allocation of phosphate within the plant and phosphate-starvation responses. Plant Cell 14(8): 1751-1766.

Versaw WK, Metzenberg RL. 1995. Repressible cation-phosphate symporters in Neurospora crassa. Proceedings of the National Academy of Sciences, USA 92(9): 3884-3887.

Walker DA, Sivak MN. 1986. Photosynthesis and phosphate: A cellular affair? Trends in Biochemical Sciences 11: 176-179.

Ward JM. 2001. Identification of novel families of membrane proteins from the model plant Arabidopsis Thaliana. Bioinformatics 17(6): 560-563. 
Werner A, Moore ML, Mantei N, Biber J, Semenza G, Murer H. 1991. Cloning and expression of cDNA for a $\mathrm{Na} / \mathrm{Pi}$ cotransport system of kidney cortex. Proceedings of the National Academy of Sciences, USA 88(21): 9608-9612.

Wykoff DD, O'Shea EK. 2001. Phosphate transport and sensing in Saccharomyces cerevisiae. Genetics 159(4): 1491-1409.

Yabuuchi H, Tamai I, Morita K, Kouda T, Miyamoto K, Takeda E, Tsuji A. 1998. Hepatic sinusoidal membrane transport of anionic drugs mediated by anion transporter Npt1. Journal of Pharmacology and Experimental Therapeutics 286(3): 1391-1396.

Zhao L, Versaw WK, Liu J, Harrison MJ. 2003. A phosphate transporter from Medicago truncatula is expressed in the photosynthetic tissues of the plant and is located in the chloroplast envelope. New Phytologist 157: 291-302.

Zimmermann P, Hennig L, Gruissem W. 2005. Gene-expression analysis and network discovery using Genevestigator. Trends in Plant Science 10(9): 407-409. 


\section{APPENDIX}

\section{PROTOCOLS}

\section{Histochemical GUS Analysis}

Reference:

Vitha, S., Beneš, K., Phillips, J.P., and Gartland, K.M.A. (1995). Histochemical GUS Analysis. In Agrobacterium Protocols, K.M.A. Gartland and M.R. Davey, eds (Totowa, NJ: Humana Press), pp. 185-193.

Reagents:

0.05 M Na-phosphate buffer, $\mathrm{pH} 7.0$

Fixative: $4 \%$ formaldehyde in phosphate buffer

Incubation medium: Dissolve 1mg 5-bromo-4-chloro-3-indolyl-D-Glucuronide (X-Gluc) in $0.1 \mathrm{~mL}$ methanol, add $1.87 \mathrm{~mL}$ phosphate buffer, $10 \mu \mathrm{l} 0.1 \mathrm{M}$ potassium ferrocyanide, $10 \mu \mathrm{l} 0.1 \mathrm{M}$ potassium ferricyanide, $10 \mu \mathrm{l} 10 \%(\mathrm{w} / \mathrm{v})$ solution of Triton X-100 $70 \%(\mathrm{v} / \mathrm{v})$ ethanol $50 \%(\mathrm{v} / \mathrm{v})$ and $100 \%(\mathrm{v} / \mathrm{v})$ glycerol

Vacuum pump and dessicator

Tissue fixation and staining:

1. Fix tissue for 30 minutes in ice cold fixative, shaking occasionally.

2. Wash fixed tissue for 30-60 minutes in several changes of ice-cold phosphate buffer.

3. Vacuum infiltrate tissues with incubation medium twice, each for $5 \mathrm{~min}$. (I used the vacuum pump in the Thomas lab and in our lab.)

4. Incubate tissue in the dark at $37^{\circ} \mathrm{C}$ for several hours or overnight until distinct blue staining appears.

5. Rinse with distilled water.

6. To clear chlorophyll, incubate tissues in $70 \%$ ethanol for several hours then transfer to distilled water.

7. Mount objects in water or glycerol on a slide and view under dissecting microscope, or compound microscope as needed. Mounting in glycerol can yield higher quality images (see below).

Glycerol mounts:

1. Place tissue in $50 \%$ glycerol for several minutes then transfer to $100 \%$ glycerol. Leave in $100 \%$ glycerol for several minutes or overnight.

2. Mount objects in 100\% glycerol on microscope slides, examine under microscope. 


\section{Sectioning of GUS Stained Plant Tissue}

Reference:

Vitha, S., Baluška, F., Jasik, J., Volkmann, D., and Barlow, P. Steedman's Wax for Factin Visualization in Actin: a Dynamic Framework for Multiple Plant Cell Functions, Staiger, C.J., Baluška, F., Volkmann, D., and Barlow, P., Editors. 2000, Kluwer:

Dordrecht, The Netherlands. p. 619-636.

Materials:

1. Phosphate buffer: $0.05 \mathrm{M}$ Na-phosphate buffer, $\mathrm{pH} 7.0$

2. Fixative:

For initial fixation: 4\% Formaldehyde in 1x phosphate buffer

For post-fixation: $4 \%$ formaldehyde $+0.5 \%$ glutaraldehyde in $1 \mathrm{x}$ phosphate buffer

3. Steedman's wax:

Melt 900g polyethylene glycol 400 distearate (Aldrich, cat. \# 30,541-3) and 100g 1-

hexadecanol (Aldrich cat. \# 25,874-1) in a large beaker in an incubator at $65^{\circ} \mathrm{C}$.

When completely melted, stir the wax thoroughly for several minutes using a stir bar.

Pour the wax in $50 \mathrm{ml}$ disposable plastic tubes and let it harden at room temperature.

4. Ethanol series: $15 \%, 30 \%, 50 \%, 70 \%, 90 \%$, 95\% and $100 \%$

5. Vacuum and dessicator

6. Microwave: Pelco Biowave, a scientific-grade microwave oven with variable power, temperature control and vacuum. (located in Microscopy Center, BSBW)

7. Microtome: MICROM HM335E (located in BSBE104, Riley lab)

Procedure:

Day1:

1. Fix GUS stained tissue for $30 \mathrm{~min}$ in ice cold initial fixative.

2. Wash tissue for 30-60 min in several changes of ice cold 1x phosphate buffer.

3. Vacuum infiltrate in staining buffer, $10 \mathrm{~min}$.

4. Keep in dark at $37^{\circ} \mathrm{C}$ overnight.

Day 2:

Preheat wax in a $65^{\circ} \mathrm{C}$ incubator.

1. Wash tissue with $1 \mathrm{x}$ phosphate buffer

2. Post-fixation

$4 \%$ formaldehyde $+0.5 \%$ glutaraldehyde in $1 \mathrm{x}$ phosphate buffer, 30 min

Microwave $1 \mathrm{~min}$ to finish fixation.

3. Wash in $1 \mathrm{x}$ buffer $3 \mathrm{x}$ in microwave, each step $1 \mathrm{~min}$.

4. Dehydrate in ethanol series. Each step $1 \mathrm{~min}$ in microwave.

$15 \% \rightarrow 30 \% \rightarrow 50 \% \rightarrow 70 \% \rightarrow$ leave until tissue clears. (Can change ethanol if needed. Can be stored at $4^{\circ} \mathrm{C}$ ) $\rightarrow 90 \% \rightarrow 95 \%$ (3x1min)

5. Move samples to 37C. (> 20 min for preheating)

6. Add wax into a vial, mix. Incubate 1-2 hr.

7. Remove half the liquid, add wax, mix, incubate 1-2 hr. 
8. Repeat step \#7.

9. Transfer to $100 \%$ wax, leave overnight.

Day 3:

Embedding in mold.

1. Put mold on a warm plate and add wax to holes in the mold.

2. Put a weighing dish on the warm plate and transfer samples to the weighing dish.

3. Use forceps to pick the samples into small cells in the mold.

4. Arrange the samples as desired using forceps.

5. Add more wax to the wells until convex because wax will shrink when it solidifies.

6. Put the mold at room temperature to solidify.

Day 4:

Remove wax from mold, section with a microtome and prepare slides. I used the microtome in Dr Bruce Riley’s lab.

1. Soak the top of a wooden stub with molten wax.

2. Warm a razor blade briefly in a flame and lay it on top of the wooden block. Place the wax block on the blade and, as the base starts to melt, slide it off the blade onto the wood. Do not use too much heat or the whole block will melt.

3. Allow the wax to harden at room temperature for about $30 \mathrm{~min}$.

4. Trim the sides of the block around the specimen with a razor blade, creating a pyramidal shape with straight, parallel edges.

5. Clamp the block into the specimen holder of a rotary microtome. Align the top face of the wax block with the blade.

6. Set the thickness of slices to $10 \mu \mathrm{m}$.

7. Rotate the arm of the microtome to cut.

8. Use a paint brush to transfer ribbons to a piece of paper.

9. Cut the ribbon into shorter pieces with a razor blade and place them on a glass slide.

10. Holding the slide with one end raised about $45^{\circ}$, add a small drop of water to let the ribbons expand. Blot to remove excess water.

11. Keep slides at an angle and let dry at room temperature for several hours or overnight.

12. Dewax in ethanol series: $100 \% \rightarrow 95 \% \rightarrow 90 \% \rightarrow 70 \% \rightarrow 50 \% \rightarrow 30 \% \rightarrow \mathrm{H}_{2} \mathrm{O}$. Each step $10 \mathrm{~min}$.

13. Remove excess water, put a coverslip on the slide and observe under compound microscope at 400x magnification. 


\section{Quantitative GUS Assay}

Adapted from a protocol provided by Dr Veria Alvarado.

Materials:

Extraction buffer $(100 \mathrm{ml})$ :

$50 \mathrm{mM}$ Sodium phosphate

$10 \mathrm{ml}$ 0.5 M Na-Phosphate buffer, $\mathrm{pH} 7.0$

$10 \mathrm{mM}$ EDTA

$2 \mathrm{ml} 0.5$ M EDTA, pH 8.0

$10 \mathrm{mM}$ Beta-mercaptoethanol

$69 \mu \mathrm{l}$

$0.1 \%(\mathrm{v} / \mathrm{v})$ Triton X-100

$0.1 \mathrm{ml}$

$0.1 \%(\mathrm{w} / \mathrm{v})$ Lauryl sulfate sarcosine

$0.1 \mathrm{~g}$ or $2 \mathrm{ml}$ of $5 \%$ stock

Extraction buffer can be made and stored at RT without beta-mercaptoethanol. Add betamercaptoethanol immediately before use.

Substrate buffer

4 mM MUG (4-methylumbelliferyl beta-D-glucuronide, triethylamine salt) in extraction buffer. To prepare, add 9 mg MUG to $5 \mathrm{ml}$ extraction buffer (without betamercaptoethanol).

Stop buffer:

$0.2 \mathrm{M} \mathrm{Na}_{2} \mathrm{CO}_{3}$

Plate Reader: Synergy HT microplate Reader (Bio-Tek Instrument), BSBE room 203

96-well plate: black plate with clear bottom (96-well Optical Btm Plt PolymerBase Black w/o lid N/Treated N/Ster PS 10/BG, NUNC)

Procedure:

1. Collect plant tissue (a few mg from 3-4 independent lines for each construct), and put in labeled, $1.5 \mathrm{ml}$ microfuge tubes.

2. Grind sample in $150 \mu \mathrm{l}$ extraction buffer.

3. Centrifuge for $20 \mathrm{~min}$ at max speed at $4^{\circ} \mathrm{C}$

4. Transfer $100 \mu \mathrm{l}$ of the supernatant to a new tube. KEEP ON ICE

5. Mix $10 \mu \mathrm{l}$ supernatant with $10 \mu \mathrm{l}$ substrate buffer (add the substrate buffer as quickly as possible). Use 96-well plates to incubate the samples for 60 minutes at 37C (the time of incubation must be measured precisely and recorded). Final substrate concentration will be $2 \mathrm{mM}$.

6. Quickly add $180 \mu \mathrm{l}$ stop buffer to terminate the reaction. For the plates, you need to transfer the sample-substrate mix into a new black plate with clear bottom (96 well Optical Btm Plt PolymerBase Black w/o lid N/Treated N/Ster PS 10/BG, NUNC ${ }^{\mathrm{TM}}$ ) ( 0 is obtained by measuring $180 \mu \mathrm{l}$ stop buffer $+10 \mu \mathrm{l}$ extraction buffer $+10 \mu \mathrm{l}$ substrate buffer). 
Standard curve:

Prepare a $10 \mathrm{mM}$ working solution of 4-MU from a $100 \mathrm{mM}$ stock. From the working solution, make standards in extraction buffer as follows: $100 \mu \mathrm{M}, 50 \mu \mathrm{M}, 10 \mu \mathrm{M}, 5 \mu \mathrm{M}$, $1 \mu \mathrm{M}$ and $0.5 \mu \mathrm{M}$. This will correspond to 2000, 1000, 200, 20 and 10 picomoles of 4MU when you add $20 \mu \mathrm{l}$ of the working solutions and $180 \mu \mathrm{l}$ of stop buffer.

7. Read plate in the fluorescence mode.

Excitation: 360/40

Emission: 580/20

Sensitivity 50

8. Protein determination (Bradford assay)

BSA is used as a standard, $2 \mu \mathrm{l}$ of known concentration $(0,0.5,1,1.5,2$ and $3 \mathrm{mg} / \mathrm{ml}$ in water) are diluted in $158 \mu \mathrm{l}$ water. Add $40 \mu \mathrm{l}$ of Biorad Bradford solution, incubate $5-15 \mathrm{~min}$ at RT then read OD at $595 \mathrm{~nm}$. The samples are treated in the same way starting with $2 \mu \mathrm{l}$ supernatant

Results:

GUS activities driven by $C a M V-35 S$, $P H T 4 ; 4$, and $P H T 4 ; 6$ promoters in transgenic shoot tissues were compared. PHT4;4 and PHT4;6 promoters yielded greater GUS activity than $C a M V-35 S$. 


\section{Hydroponic Growth of Arabidopsis}

Reagents:

Container: 1.5L, (24x14x5 cm), completely opaque

Lid: US Plastics Cat. 42500 Black epoxy PVC sheet 0.25 " thick

Sheets are cut to match the container, 24 holes drilled for seed holders.

Seed holder: $250 \mu$ l thin-walled PCR tube filled with 0.5x MS agar (0.65\% agar)

Procedure:

1. Make $0.5 x$ MS medium with $0.65 \%$ agar (no sugar, microwave to melt, not sterile). Put several PCR tubes into a tip box (for yellow tips), and fully fill them with molten 0.5x MS agar. An Arabidopsis seed (non-sterile) is placed in each seed holder then held at $4^{\circ} \mathrm{C}$ for two or more days. Tip boxes are wrapped with saran to maintain moisture.

2. Transfer cold-treated seed holders to the growth chamber (150 $\mu \mathrm{molm}^{-2} \mathrm{~s}^{-1}$ light), and keep wrapped for one week. Most seeds will germinate and grow into small seedlings with 2 cotyledons and 2 very tiny true leaves within this week.

3. Fill containers with $0.5 x$ MS liquid (no sugar) and cover them with lids. Cut off the bottom of the seed holders (avoid the roots), and insert them into the holes in the lid. Be sure that the seed holders are in contact with the liquid.

4. Three containers can be placed in a row and covered by a plant dome. Keep the dome in place for 3 or 4 days to slowly equilibrate with the humidity of the growth chamber.

5. If plants are going to be grown for 3 weeks or less, the media doesn't need to be changed. For growth longer than 3 weeks, replace the media weekly and check the level daily. Add more as needed to maintain contact with the seed holder. 


\section{Quantitative RT-PCR}

Reagents:

Power SYBR Green PCR Master Mix (ABI)

Micro Amp. Fast Optical 96-well reaction plate with Barcode (0.1 ml) (ABI)

Applied Biosystems Fast 7500 Real-Time PCR System

Sampling strategy:

For most experiments, Arabidopsis plants are grown in soil or hydroponics for about 3 weeks and harvested before bolting. If only shoots are needed, take whole above ground part of 2 seedlings and pool these as one biological sample. Place the tissues in a foil pouch and freeze in liquid nitrogen. At least 2 biological replicates are needed for each data point, but an additional 1-2 replicates should be frozen to expedite follow-up studies.

RNA isolation and cDNA synthesis:

Isolate total RNA using the TRI reagent protocol (Sigma) then remove traces of DNA with TURBO DNA-free (Ambion). Determine the RNA concentration by absorbance at $260 \mathrm{~nm}$, and adjust samples to the same concentration. I adjust samples to $0.125 \mu \mathrm{g} / \mu \mathrm{l}$, and use $8 \mu \mathrm{l}(1 \mu \mathrm{g})$ to make cDNA with the SuperScript first-strand cDNA synthesis kit (Invitrogen). Dilute the cDNA from $20 \mu \mathrm{l}$ to $100 \mu \mathrm{l}$ with water.

To assess cDNA quality and absence of genomic DNA, amplify $1 \mu \mathrm{l}$ of the cDNA mix with EIF-4A2 primers (5'-CAAGGTGTCAAGGTTCATGC-3' and 5'-

CAACGACAACATGAACACCA-3'). A 492 bp amplicon is produced from cDNA and 693 bp from genomic DNA.

Real-time PCR:

1. Set up reactions in 96-well plate on ice as follows:

cDNA

$5 \mu \mathrm{l}$

Primer $1(5 \mu \mathrm{M}) \quad 2 \mu \mathrm{l}$

Primer $2(5 \mu \mathrm{M}) \quad 2 \mu \mathrm{l}$

$\mathrm{H}_{2} \mathrm{O} \quad 1 \mu \mathrm{l}$

SYBR Green (2x) $10 \mu \mathrm{l}$

$20 \mu \mathrm{l}$

Because SYBR Green is sensitive to light, cover the tube and the plate with a piece of paper.

2. Seal plate with film.

3. Spin plate at $2200 \mathrm{rpm}$ for $1 \mathrm{~min}$ to mix. (Centrifuges with plate adapters are located in the Thomas and Cassone labs)

4. Carry plate on ice to BSBW room 017 to access ABI 7500 thermalcycler.

5. Double click on “7500 Fast System Software” icon.

6. File>new document

7. Change "Run mode" into 9600 emulation and name your plate, then click "Next" 
8. Select detectors from left window and click “add”, all detectors needed for the reaction will appear in the right window. Then, click "next".

For example, if you want to detect PHT2;1 levels in a mutant, you used PHT2;1 primers and EIF-4A2 primers in your reaction, then you need to select "PHT2;1" from the left list by highlighting it and then click "add", and then do the same thing to add "EIF-4A2" detector.

9. Highlight the squares according to your arrangement of reactions in your plate, and click on the corresponding detector. Then, click "Finish".

For example, if in your plate, reactions in row "A" are for amplification of PHT2;1, you highlight A row by dragging the mouse and then click on detector PHT2;1.

10. Go to View $>$ Well Inspector. A window will appear. Click on one well to select it, or drag your mouse to select several wells at one time, then type in the sample name in the well inspector window. For the wells without a reaction, select them and click in the checkbox "omit well". Close well inspector window.

11. Click on "Instrument" tab. You will be able to view the reaction program. Check if it's correct then click “Add disassociation Stage”.

The correct program should be:

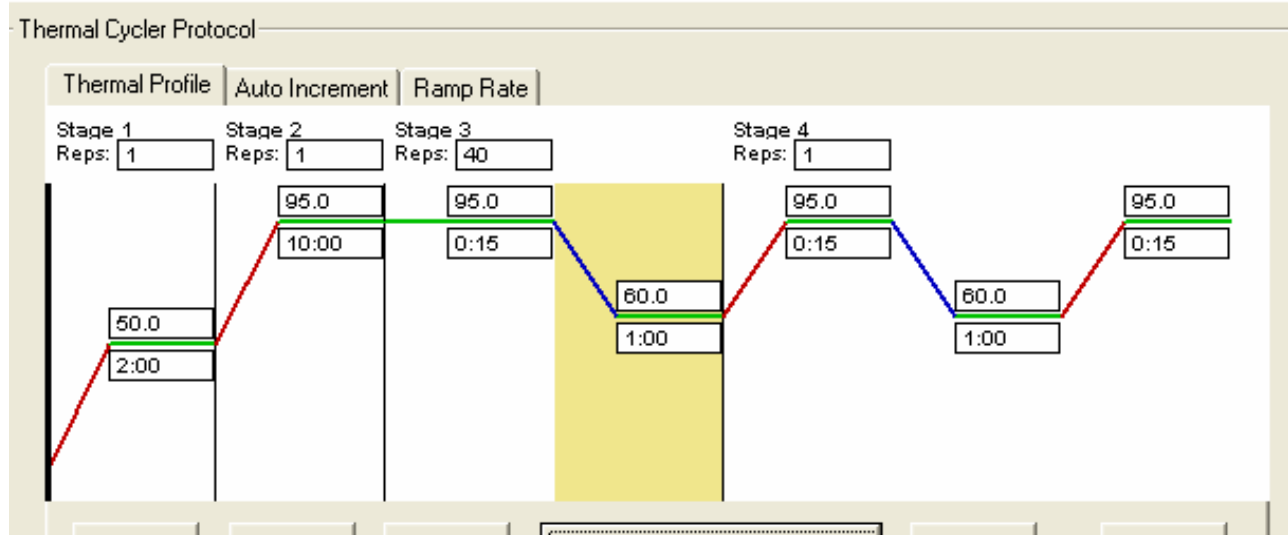

12. Go to File>Save, and save document in your folder.

13. Put plate into Real-Time PCR machine. Click "start” and wait until a count down timer appears, then you can leave the room. Return in about 3 hours.

14. To get your results, go to Analysis $>$ analyze. Then go to File $>$ Export $>\mathrm{Ct}$, all the $\mathrm{Ct}$ values will be saved in a file that can be opened in Excel. 


\section{PCR Screen for PHT4 Insertion Mutants}

Screening strategy:

Plant Growth:

1. Place a 24-well section cut from a 72-well inert in a flat and fill the wells with dry Redi-earth (Sun Gro Horticulture). Use the sprinkler attached to the sink in the planting area to wet the Redi-earth until water begins to flow through. Fully moistened wells should feel more compacted than when dry or partially wetted.

2. Carefully shake dry Arabidopsis seeds onto a dry Whatman filter. Use fine-tipped forceps to transfer a single seed into each of the 24 wells. Fill out a plastic label with plant stock number or other name, date and your initials then insert in one representative well. You will have to trim the label so it is not too tall.

3. Cover the flat with a plastic dome, secure with tape and label with your name and the date. Place in cold room for 3 days.

4. Transfer the flat to a top shelf in growth chamber.

Growth chamber settings are 14/10hr light/dark, 21C, 60\% Rel. humidity, $150 \mu \mathrm{E}$ light intensity.

5. After $\sim 7$ days in the growth room, lift one edge of the plastic dome to let the plants slowly acclimate to the humidity of the room. After 1 day the dome can be removed.

6. Monitor the plants daily for growth and moisture. Often a light misting is all that is necessary. If more water is needed, add slowly to the bottom of the flat and let the water soak upward. Do not leave the plants in standing water. Wait until true leaves have emerged (about 2 weeks) before proceeding to the PCR screening step.

\section{PCR screen 1:}

1. Use the Plant Extract-N-Amp kit (Sigma) as directed to isolate genomic DNA from one leaf from each plant. Save unused extracts at $4^{\circ} \mathrm{C}$ for next screen steps.

2. Prepare two gene-specific primers and one insert-specific primer for initial screen (this should also define zygosity). Primers stored at $100 \mu \mathrm{M}$ are diluted to $10 \mu \mathrm{M}$ working concentration.

3. PCR conditions are as follows:

$\begin{array}{lrll}\text { water } & 3 \mu \mathrm{l} & \underline{94^{\circ} \mathrm{C}} & 3 \mathrm{~min} \\ \text { PCR rxn mix } & 10 \mu \mathrm{l} & 94^{\circ} \mathrm{C} & 30 \mathrm{sec} \\ \text { Primer } 1 & 1 \mu \mathrm{l} & 60^{\circ} \mathrm{C} & 30 \mathrm{sec} \\ \text { Primer } 2 & 1 \mu \mathrm{l} & \underline{72^{\circ} \mathrm{C}} & 1 \mathrm{~min} 35 \text { cycles } \\ \text { Insert primer } & 1 \mu \mathrm{l} & 72^{\circ} \mathrm{C} & 5 \mathrm{~min} \\ \text { Extract } & 4 \mu \mathrm{l} & 10^{\circ} \mathrm{C} & \text { hold } \\ \text { Total } & 20 \mu \mathrm{l} & & \end{array}$

Run $5 \mu \underline{\text { l }}$ on a $1 \%$ agarose gel to evaluate amplification. 
PCR screen 2:

Use remaining extract from PCR screen 1 to amplify both insert junctions from lines that scored positive in screen 1. Use PCR conditions as previous and evaluate products by gel. If products match the expected outcomes, clean with Qiagen kit and sequence. Positive plants can be transplanted to pots for further growth and seed set. Make certain to keep plants separated and clearly labeled. Save seed from all homozygous positives. If no homozygous positives are found, save the hemizygous plants and allow these to self.

Evaluation of homozygous mutants:

1. RT-PCR to see determine if transcript level is reduced/absent.

2. Southern blot to determine insert copy number.

Results:

The following mutant lines were screened and confirmed as null mutants:

$\begin{array}{llll}\text { Stock \# } & \text { Gene name } & \text { AGI code } & \text { Insertion site (confirmed by sequencing) } \\ \text { 1. CS171768 } & \text { PHT4;1 } & \text { At2g29650 } & \text { exon 1 (177/178) } \\ \text { 2. SALK_019289 } & \text { PHT4;2 } & \text { At2g38060 } & \text { exon } 5(2170 / 2177) \\ \text { 3. SALK_121537 } & \text { PHT4;5 } & \text { At5g20380 } & \text { exon 3 (821/855) } \\ \text { 4. FLAG_473D01 } & \text { PHT4;5 } & \text { At5g20380 } & \text { exon 1 (291/right border not sequenced yet) }\end{array}$

The following mutant lines were screened, but are not null or do not contain the predicted insertion:

$\begin{array}{llll}\text { Stock \# } & \text { Gene name } & \text { AGI code } & \begin{array}{l}\text { Description of the line } \\ \text { 1. SALK_053900 }\end{array} \\ \text { PHT4;3 } & \text { At3g46980 } & \text { Transcript level is the same as in wild type. } \\ \text { 2. CS82896 } & \text { PHT4;3 } & \text { At3g46980 } & \text { Transcript level is the same as in wild type. } \\ \text { 3. SALK_121633 } & \text { PHT4;5 } & \text { At5g20380 } & \text { No insertion detected. } \\ \text { 4. CS178307 } & \text { PHT4;4 } & \text { At4g00370 } & \text { No insertion detected. }\end{array}$




\section{MS Media Recipes}

Murashige \& Skoog Medium

Reference: Murashige, T., Skoog, F., 1962, Physiologia Plantarum 15:473-497

I usually prepare medium at $0.5 \mathrm{x}$ final concentrations, but $1 \mathrm{x}$ also works fine.

10x MS Macronutrients (g/L) filter sterilize, store at 4C

Ammonium Nitrate $\quad 16.500$

Calcium Chloride- $2 \mathrm{H}_{2} \mathrm{O} \quad 4.397$

Magnesium Sulfate Anhydrous $\quad 1.807$

Potassium Nitrate $\quad 19.000$

Potassium Phosphate monobasic $\left(\mathrm{KH}_{2} \mathrm{PO}_{4}\right) \quad 1.700 \quad(0.625 \mathrm{mM}$ at $0.5 \mathrm{x})$

10x MS Micronutrients (mg/L) filter sterilize, store at 4C

Boric Acid 62.00

Cobalt Chloride- $6 \mathrm{H}_{2} \mathrm{O}$

Cupric Sulfate- $5 \mathrm{H}_{2} \mathrm{O} \quad 0.25$

Ferrous Sulfate- $7 \mathrm{H}_{2} \mathrm{O} \quad 278.00$

Manganese Sulfate- $\mathrm{H}_{2} \mathrm{O} \quad 169.00$

Molybdic Acid Sodium Salt- $2 \mathrm{H}_{2} \mathrm{O} \quad 2.50$

$\mathrm{Na}_{2}$-EDTA-2 $\mathrm{H}_{2} \mathrm{O} \quad 372.60$

Potassium Iodide $\quad 8.30$

Zinc Sulfate- $7 \mathrm{H}_{2} \mathrm{O}$

1000x MS Vitamins (mg/ml) filter sterilize, store at 4C

Glycine 2.0

myo-Inositol $\quad 100.0$

Nicotinic acid 0.5

Pyridoxine-HCl $\quad 0.5$

Thiamine-HCl $\quad 0.1$

Complete medium at $0.5 \mathrm{x}$ should be adjusted to $\mathrm{pH} 5.7$

For agar-solidified medium, add agar (Sigma, A-1296) to 0.7\%.

Sucrose can be added at $1 \%$ if desired. Seedlings grow better with sucrose but so do microbes.

Specialized MS media

MS-Pi Medium

Use 10x MS Macronutrients in which potassium sulfate $\left(1.088 \mathrm{~g} / \mathrm{L} \mathrm{K}_{2} \mathrm{SO}_{4}\right)$ is substituted for potassium phosphate to make up the deficit in potassium ions. 
MS, low-N Medium

10X MS Low-N Macronutrients (g/L):

ammonium nitrate 0.165

calcium chloride- $2 \mathrm{H}_{2} \mathrm{O}$

magnesium sulfate (anhydrous) $\quad 1.807$

potassium nitrate 0.19

potassium phosphate monobasic $\quad 1.7$

When used at $0.5 \mathrm{x}$ the final $\mathrm{N}$ concentration will be $0.3 \mathrm{mM}$.

To screen for phenotypes, I grew mutant and wild-type plants side by side under conditions to examine the effect of Pi concentration, sucrose concentration, osmotic pressure, salinity and low $\mathrm{N}$.

Pi concentrations used:

10, 20, 50, 100, 200, 1000, 2000 and $4000 \mu \mathrm{M}$ Pi (1\% Sucrose)

Sucrose concentrations used:

$0 \%, 1 \%, 3 \%, 6 \%$ and $9 \%$ sucrose

Sorbitol concentrations used to investigate osmotic pressure:

50, 100, 200, and $300 \mathrm{mM}$ sorbitol

$\mathrm{NaCl}$ concentrations used to investigate the effect of salinity:

50, 100, 150, and $200 \mathrm{mM} \mathrm{NaCl}$

Results:

Wild-type and mutant plants exhibited altered growth in response to the different environmental conditions tested (reduced growth at extreme conditions), but no obvious genotype-dependent differences were detected. 


\section{Starch Staining of Plant Tissues}

Reagents:

$80 \%$ ethanol

$\mathrm{I}_{2}$ /KI solution: (5 g KI, $0.5 \mathrm{~g} \mathrm{I}_{2}, 500 \mathrm{ml} \mathrm{H}_{2} \mathrm{O}$ )

Procedure:

1. Place seedlings in a glass beaker containing $80 \%$ ethanol.

2. Boil seedlings until green color clears. In most cases, clearing is complete within 10 minutes. Change ethanol as needed.

3. Remove seedlings from ethanol and rinse with water.

4. Decant water, add $50 \mathrm{ml} \mathrm{I}_{2} / \mathrm{KI}$ solution, and let sit for $5 \mathrm{~min}$.

5 . Decant $\mathrm{I}_{2} / \mathrm{KI}$ solution. Rinse with water until the water is clear.

6. Take picture within 30 minutes.

Note:

If stained seedlings stay in water for over $1 \mathrm{hr}$, staining will fade. Also, if the amount of water added to the beakers is different, the stained seedlings will lose color at different rates.

Results:

Starch accumulation in 3-week-old wild type (Ler), wild type (Col-0), pht4;1-1, and pht4;5-1 plants were tested. These plants were grown under $14 \mathrm{hr}$ photoperiod with 150 $\mu \mathrm{mol} / \mathrm{m}^{2} \mathrm{~s}$ light intensity. Under this condition, pht4;5-1 (Col-0 background) showed increased starch accumulation at the end of the day when compared with wild type (Col0 ). No difference between pht4;1-1(Ler background) and wild type (Ler) were detected. 


\section{Chloroplast Morphology Protocol}

References:

Miyagishima, S.Y., Froehlich, J.E., Osteryoung, K.W. 2006. PDV1 and PDV2 mediate recruitment of the dynamin-related protein ARC5 to the plastid division site. Plant Cell 18: 2517-2530.

Chloroplast 2010 web site: http://www.plastid.msu.edu/

Reagents:

3.5\% glutaraldehyde (Prepare fresh from 50\% stock solution)

$0.1 \mathrm{M} \mathrm{Na}_{2}$ EDTA, pH 9.0

Tissue fixation: $\quad$ All work with glutaraldehyde must be done in a fume hood

1. For each tissue sample, add $1 \mathrm{ml} 3.5 \%$ glutaraldehyde to a well of a 48-well culture plate.

2. Using tweezers, carefully remove the tip $(0.5-1 \mathrm{~cm})$ of a fully expanded, green leaf and place in a well. Do not use leaves that turned yellow or are dying/dead.

3. Cover the plate and keep in dark at RT for 1 hour.

4. Remove the glutaraldehyde from each well using a Pasteur pipette, and discard in the hazardous waste container.

5. Add $1 \mathrm{ml} 0.1 \mathrm{M}$ EDTA to each well, close the lid again and put in the $55^{\circ} \mathrm{C}$ incubator for 2 hours.

6. Remove the plate from the oven and cool at RT for 10 minutes. Plates can be wrapped in plastic film and stored at $4^{\circ} \mathrm{C}$ for up to 3 days.

Slide preparation and sample viewing:

1. Put a small drop of water on a slide then place a fixed leaf sample in the water drop. Cover the sample with a coverslip.

2. Gently tap the coverslip with the eraser end of a pencil to separate cells. Blot excess water.

3. View the sample at 400x magnification (40x objective) with Nomarski DIC optics. Scan for chloroplasts within cells. Note the number of chloroplasts per cell, and the size and shape of chloroplasts. Capture at least two representative images for each sample, more if abnormalities are seen.

Results:

Samples were prepared from 3-week-old plants of the following genotypes:

Wild type (Ler), Wild type (Col), pht4;1-1 (Ler background) and pht4;5-1 (Col background)

No obvious phenotypes were detected. 


\section{VITA}

Name: $\quad$ Biwei Guo

Address: $\quad$ Department of Biology

Texas A\&M University

College station, TX 77843-3258

Fax: 979-845-2891

Email Address: guoba@tamu.edu

Education: $\quad$ B.S., Biology, Wuhan University, Wuhan, China, 2004

M.S., Biology, Texas A\&M University, 2008 